\title{
Pleistocene rhinoceros from Bogovina Cave: The first report of Stephanorhinus hundsheimensis Toula, 1902 (Mammalia, Rhinocerotidae) from Serbia
}

\author{
Predrag Radović, Miloš Radonjić, and Emmanuel M.E. Billia
}

\begin{abstract}
Finds of Pleistocene rhinoceros are rare in Serbia, and only one species (the woolly rhinoceros Coelodonta antiquitatis Blumenbach, 1799) has been reported so far. The current paper presents the dental material of an extinct so-called Hundsheim rhinoceros, Stephanorhinus hundsheimensis Toula, 1902 from Bogovina Cave (Eastern Serbia). Both the morphological and metric characteristics of the teeth are consistent with the attribution to $S$. hundsheimensis. Unfortunately, the rhinoceros material originated from an uncertain geological context, so there is no firm basis for dating. However, a potential association with a caballoid horse tooth could hint at an age of $600 \mathrm{ka}$ or less for the assemblage, which would indicate a relatively late date for the Hundsheim rhinoceros from Bogovina Cave.
\end{abstract}

Predrag Radović. National Museum Kraljevo, Trg Svetog Save 2, 36000 Kraljevo, Serbia.

pedja_radovic@yahoo.com

Miloš Radonjić. University of Belgrade, Faculty of Mining and Geology, Department of Regional Geology,

Kamenička 6, 11000 Belgrade, Serbia.milos.radonjic@rgf.bg.ac.rs

Emmanuel M.E. Billia. Independent Researcher, via Dalmazia 1, 33010 Feletto Umberto (Udine), Italy.

e.billia@yandex.ru

Key words: Pleistocene; rhinoceros; Stephanorhinus hundsheimensis; Serbia

Submission: 24 March 2019. Acceptance: 13 July 2020.

\section{INTRODUCTION}

The rhinocerotid fossil record of Serbia is generally poor and low in taxonomic diversity. A small number of specimens are known from the Miocene of Serbia, including Dicerorhinus aff. sansaniensis Lartet, 1851 (recte Lartetotherium aff. sansaniensis) (Pavlović, 1963), and an unidentified rhinoceros from the Middle Miocene (Mammal Neogene

Radović, Predrag, Radonjić, Miloš, and Billia, Emmanuel M.E. 2020. Pleistocene rhinoceros from Bogovina Cave: The first report of Stephanorhinus hundsheimensis Toula, 1902 (Mammalia, Rhinocerotidae) from Serbia. Palaeontologia Electronica, 23(2):a34. https:// doi.org/10.26879/985

palaeo-electronica.org/content/2020/3099-hundsheim-rhino-from-serbia 
(MN) zone 6) of Prebreza (Toplica, Southern Serbia; Ćirić, 1960; Stefanović, 2002-03; Stefanović and Mijović, 2004). Only one species, the woolly rhinoceros (Coelodonta antiquitatis Blumenbach, 1799), has been documented in the Pleistocene of Serbia so far (Marković, 1998; Nedeljković, 2006). This paper reports on rhinoceros dental remains originating from Bogovina Cave [Bogovinska pećina], situated at the south-eastern foothills of Kučaj Mt. near the town of Boljevac in Eastern Ser-

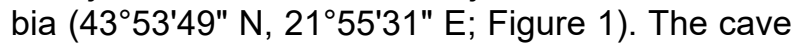
is set in Upper Jurassic to Lower Cretaceous limestones of the Kučaj zone (Dimitrijević, 1997) in the central part of the Carpatho-Balkanides. This approximately $1,200 \mathrm{~m}$ thick succession of predominantly shallow-water limestones dips steeply $\left(\sim 45^{\circ}\right)$ towards the east (Veselinović et al., 1964). The older Paleozoic clastics, which underlie these karstified limestones, act as hydrogeological barriers, which played a significant role in the formation of Bogovina Cave. Upper Cretaceous to Paleogene siliciclastic, carbonate, and volcaniclastic formations of the so-called Timok Magmatic Complex (Banješević, 2010) cover the western foothills of Kučaj Mt. in the vicinity of the cave. The youngest sedimentary formations are found on the western rim of the Bogovina Basin, a tectonic depression filled with up to $380 \mathrm{~m}$ thick Upper Oligocene to Upper Miocene sediments with coal deposits (Cvetičanin and Novković, 1975; Petrović, 1977).
With $6 \mathrm{~km}$ of explored channels, Bogovina Cave is one of the largest in Serbia (Milanović, 2015), and it is categorized as a spelaeological Natural Monument (Maran, 2010). The fossil material presented in this paper was collected in 1998 at the entrance to the cave where it was probably transported by a temporary cave stream, which is known to be active during high water periods (Pušić and Stevanović, 1994; Dokmanovic et al., 2003; Milanović, 2015). Although the primary geological context of the fossils could not be determined, the fossil material from Bogovina Cave is nevertheless important due to the scarcity of rhinoceros fossils from Serbia.

\section{MATERIALS AND METHODS}

The fossil material from the locality of Bogovina Cave (Serbia) is stored in the collections of the National Museum Kraljevo (abbreviated NMKVRS) and the Homeland Museum Paraćin (HMP). Rhinoceros remains studied in this paper include: NMKVRS.P13, left P3 or P4; HMP-139b, right P3 or P4; HMP-139a, right $\mathrm{p} 2$; HMP-407, right p3; HMP-130, right deciduous tooth (DP4); HMP-131, right $\mathrm{M} 1$ or $\mathrm{M} 2$; $\mathrm{HMP}-\mathrm{X}$, right $\mathrm{M} 1$ or M2; $\mathrm{HMP}-135$, left M1 or M2; HMP-136, right M1 or M2; HMP-132 and HMP-134, right upper molar fragments; HMP129 , right $\mathrm{m} 1$ or $\mathrm{m} 2$. This paper also reports fragments belonging to other mammalian taxa, includ-

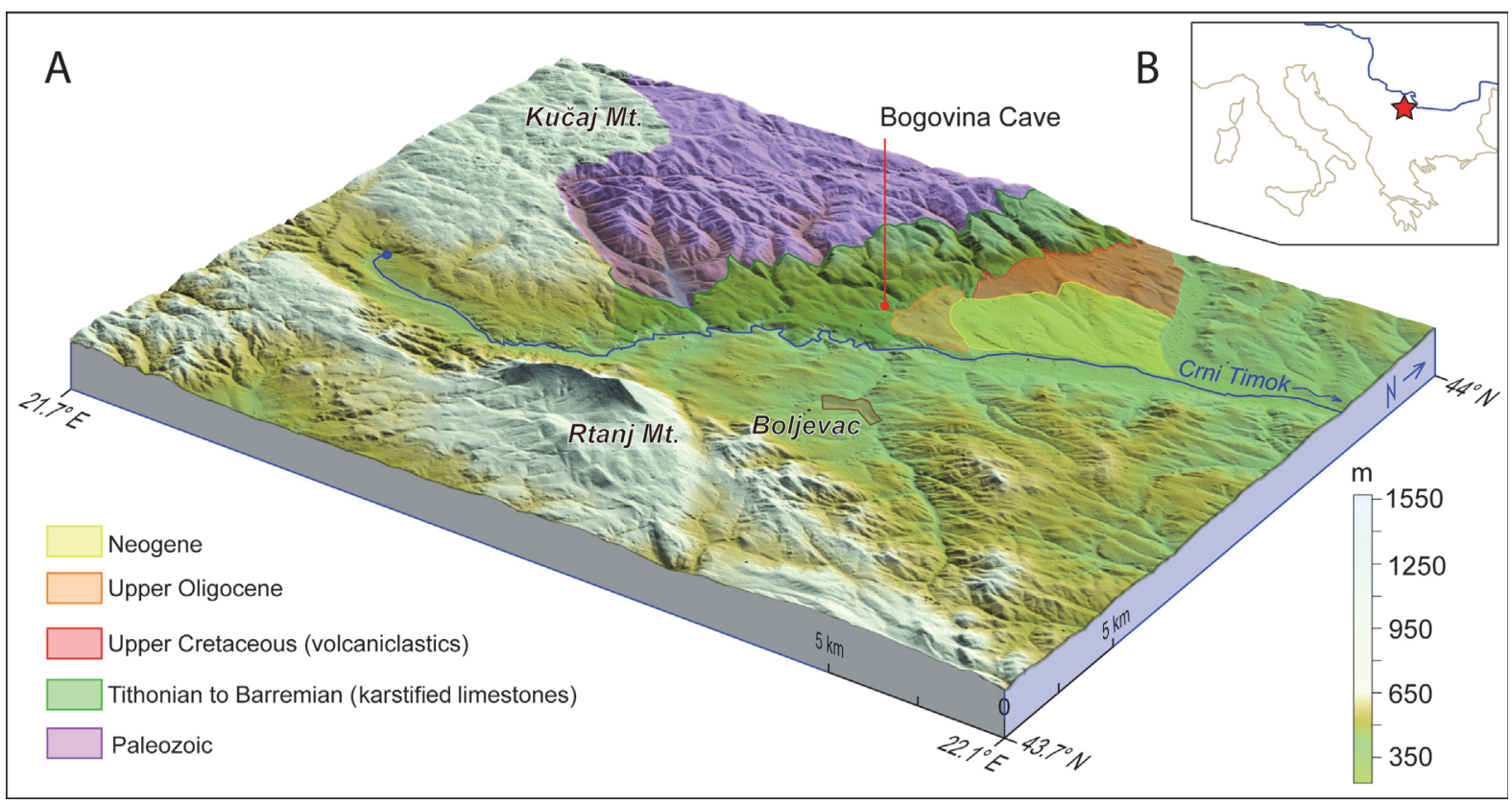

FIGURE 1. Geographical and geological location of Bogovina Cave. A) Terrain in the vicinity of Bogovina Cave with simplified geological map (after Veselinović et al., 1964). Elevation of the terrain is exaggerated several times. B) Position of Bogovina Cave in the central part of the Balkan Peninsula. 

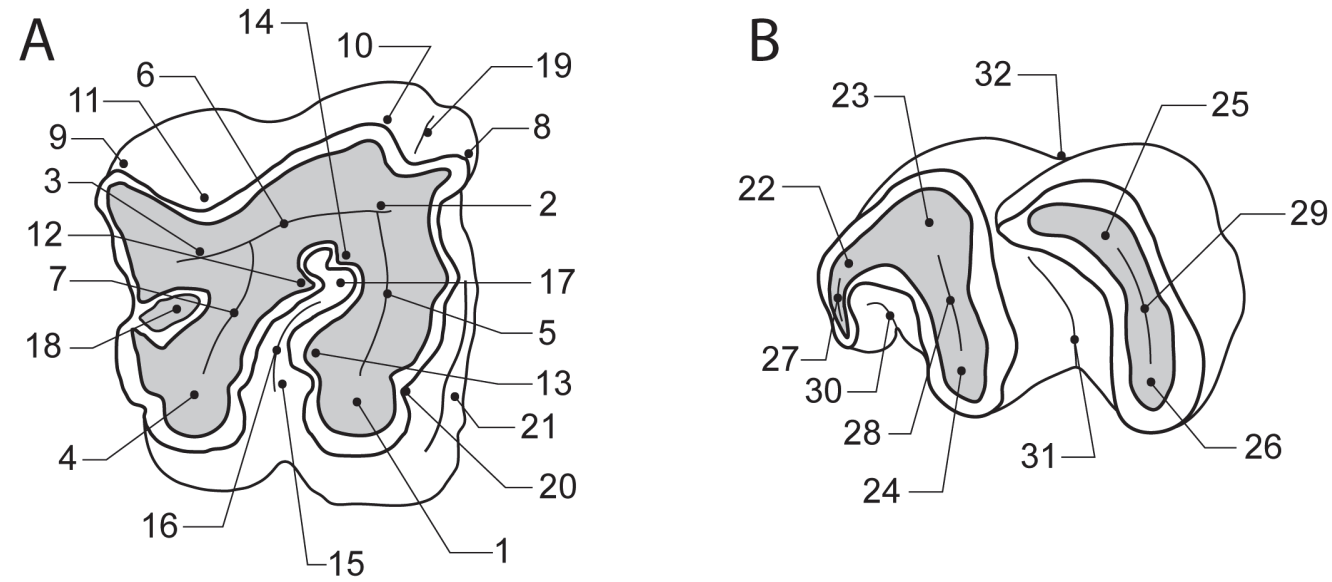

FIGURE 2. Dental terminology of rhinoceros cheek teeth (figure adapted from Fukuchi et al., 2009). A) Upper dentition: 1, protocone; 2, paracone; 3, metacone; 4, hypocone; 5, protoloph; 6, ectoloph; 7, metaloph; 8, parastyle; 9, metastyle; 10, paracone rib; 11, metacone rib; 12, crochet; 13, antecrochet; 14, crista; 15, lingual valley; 16, medisinus; 17, anterior fossetta; 18, postfossetta; 19, paracone fold; 20, protocone constriction; 21, mesial cingulum. B) Lower dentition: 22, paraconid; 23, protoconid; 24, metaconid; 25, hypoconid; 26, entoconid; 27, paralophid; 28 , metalophid; 29 , hypolophid; 30, mesial valley; 31 , distal valley; 32, vestibular syncline.

ing: NMKVRS.P11, equid left lower molar (probably m2); NMKVRS.P14 and NMKVRS.P15, bovid right p4 and left M1/M2, respectively.

The present paper considers morphological characteristics reported by several authors, including Guérin (1980), Fortelius et al. (1993), Lacombat (2006a, 2007), Ballatore and Breda (2013), Pandolfi and Marra (2015), Handa and Pandolfi (2016), and Pandolfi and Erten (2017); the dental terminology is presented in Figure 2. Measurements (in $\mathrm{mm}$ ) were taken with a digital caliper to $0.01 \mathrm{~mm}$ and rounded to the nearest $0.1 \mathrm{~mm}$. The reported measurements for rhinoceros teeth follow Fortelius et al. (1993): length - L (i.e., vestibular length) and width - W (i.e., mesial width for upper teeth, and distal width for lower teeth). The dimensions of Bogovina rhinoceros teeth were compared to the size ranges for $S$. etruscus, S. hundsheimensis, S. hemitoechus, and S. kirchbergensis, which were obtained based on the data reported by Fortelius et al. (1993), Guérin (1980), Handa and Pandolfi (2016), Pandolfi and Erten (2017), and Pandolfi and Marra (2015). The methodologies concerning bovid and equid teeth follow Gentry (1999) and Eisenmann et al. (1988), respectively. The dental anatomical notation follows the system proposed by Smith and Dodson (2003) for mammalian dentition, where premolars and molars in upper jaws are abbreviated as $\mathrm{Pn}$ and $\mathrm{Mn}(\mathrm{n}=$ tooth number) and as $\mathrm{pn}$, and $\mathrm{mn}$ in lower jaws, while deciduous teeth are indicated by D (e.g., DP4 for deciduous upper fourth premolar).

\section{RESULTS}

\section{Systematic Palaeontology}

The taxonomical position of Stephanorhinus hundsheimensis is as follows (in compliance with the criteria proposed by McKenna and Bell, 1997, except for the genus):

Class MAMMALIA Linnaeus, 1758

Subclass THERIA Parker and Haswell, 1897 Infraclass EUTHERIA Gill, 1872

Grandorder UNGULATA Kaup, 1766

Mirorder ALTUNGULATA Prothero and Schoch, 1989

Order PERISSODACTYLA Owen, 1848

Suborder CERATOMORPHA Wood, 1937

Infraorder TAPIROMORPHA Haeckel, 1866

Superfamily RHINOCEROTOIDEA Gray, 1825

Family RHINOCEROTIDAE Gray, 1821

Subfamily RHINOCEROTINAE Gray, 1821

Tribe RHINOCEROTINI Gray, 1821

Subtribe RHINOCEROTINA Gray, 1821

Infratribe RHINOCEROTI Gray, 1821

Genus STEPHANORHINUS Kretzoï, 1942

Type species. Stephanorhinus etruscus Falconer, 1868. 
A
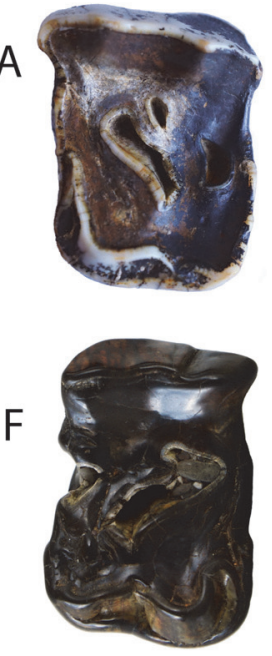

B
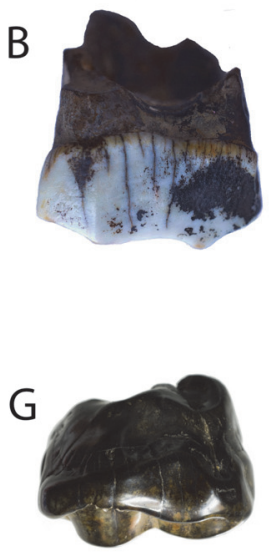
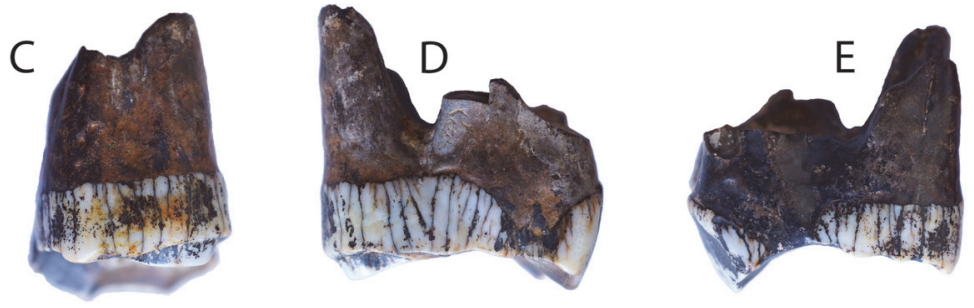

$\mathrm{H}$

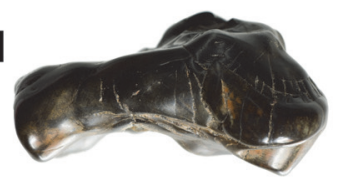

$5 \mathrm{~cm}$

FIGURE 3. Upper premolars of Stephanorhinus hundsheimensis from Bogovina Cave: left P3/P4 NMKVRS.P13 in (A) occlusal, $(B)$ vestibular, (C) lingual, (D) mesial and (E) distal views; right P3/P4 HMP-139b in (F) occlusal, (G) lingual, and $(\mathrm{H})$ distal views.

Referred species. Stephanorhinus kirchbergensis Jäger, 1839; S. hemitoechus Falconer, 1859; S. hundsheimensis Toula, 1902; S. yunchuchenensis Chow, 1963; S. jeanvireti Guérin, 1972; S. lantianensis $\mathrm{Hu}$ and Qi, 1978; possibly S. miguelcrusafonti Guérin and Santafé-Llopis, 1978, and S. africanus Arambourg, 1970.

\section{Stephanorhinus hundsheimensis Toula, 1902}

Holotype. Skeleton 2013/0282/0001 (Natural History Museum Vienna, Austria).

Type locality and horizon. Hundsheim (Lower Austria), early Middle Pleistocene (MIS 15-13).

Occurrence. Latest Villafranchian and Galerian, late Early and early Middle Pleistocene of Europe (1.4-1.2 Ma until 0.6-0.5 Ma), and possibly Late Pleistocene of Western Asia (Caucasus).

\section{Description.}

Upper dentition: The specimen NMKVRS.P13 (Figure $3 A-E$ ) is a left P3 or P4. Despite pronounced wear, this middle-large sized tooth is rather wellpreserved, consisting of a complete crown (showing grey enamel and dark brown dentine) and partially preserved roots. The enamel surface is characterised by the presence of several dark vertical and subvertical lines (these lines may frequently be present but are not ubiquitous among Pleistocene rhinoceroses). The crown displays some rounding and polishing, indicating water transport as a taphonomic agent. The surface bears patches of black manganese coating and yellowish iron-oxide staining. In occlusal view, the crown is vestibulo-lingually wide and mesio-distally short, showing a rectangular outline. The occlusal surface is semi-smooth and polished showing the interior valley, the medifossetta, as well as the postfossetta. Mesially, the ectoloph curves quite drastically towards the interior of the tooth. No constriction of the protocone can be observed. An oblique lingual cingulum is present.

The fossil designated HMP-139b (Figure 3F$\mathrm{H}$ ) is a right P3 or P4, consisting of a damaged dark brown crown with very pronounced rounding and polishing presumably by water transport. Large parts of the mesial, distal, and vestibular enamel are missing. The preserved occlusal surface shows marked wear, the presence of an interior valley, a single crochet, and the postfossetta. A partially preserved cingulum is present on the lingual and distal sides. The protocone seems to display a very slight constriction, although the pronounced wear makes this difficult to assess.

HMP-131 (Figure 4A-E) is a rather well-preserved and complete crown of a large right molar (M1 or M2), with little wear, showing grey-yellow enamel, with extensive black manganese coating. The crown does not display much taphonomicallyinduced rounding or polishing. In occlusal view, the tooth is trapezoidal showing a well-marked ectoloph profile with a strong paracone fold, an open medisinus, a single crochet, and the postfossetta. Very shallow expressions of the antecrochet and crista can be observed; if the specimen showed more advanced wear, these features would have not been observed. The base of the protoloph appears rather bulbous (especially in lingual view); the protocone shows only a very slight constriction. In both the mesial and distal views the molar 
A

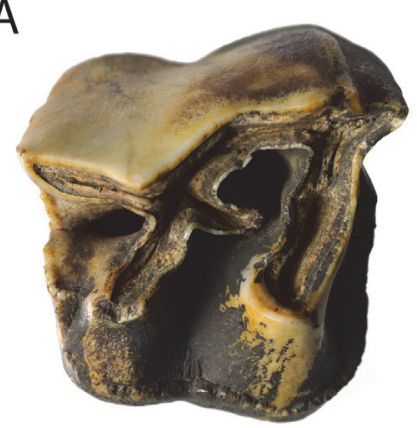

B

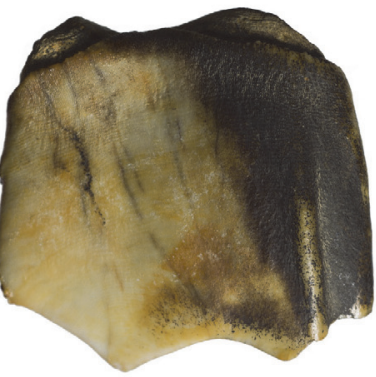

C

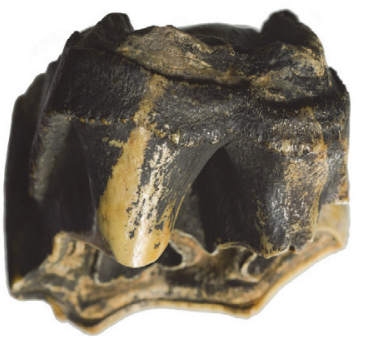

D

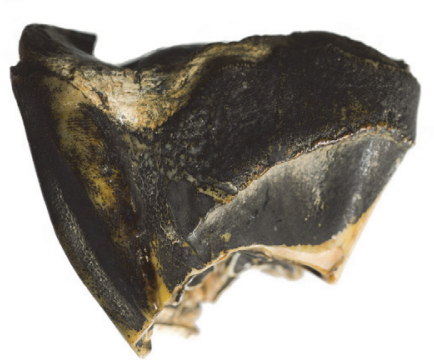

E

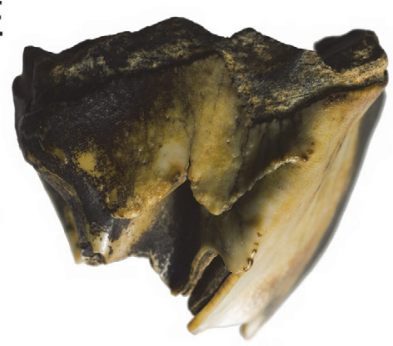

F

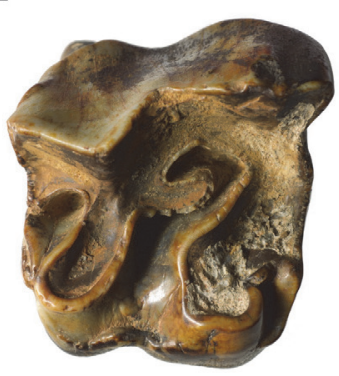

G

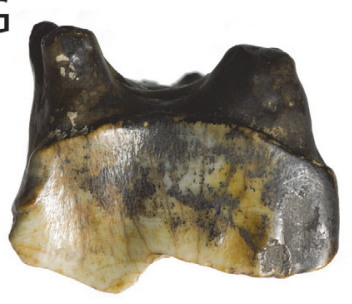

$\mathrm{H}$
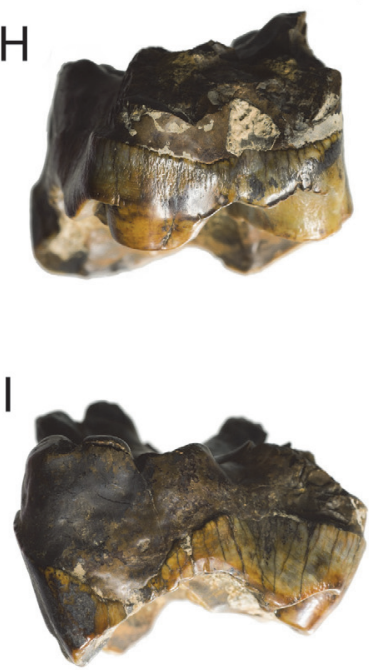

J

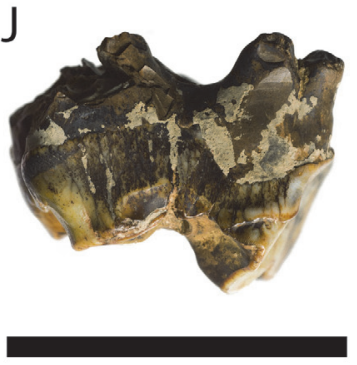

\section{$5 \mathrm{~cm}$}

K

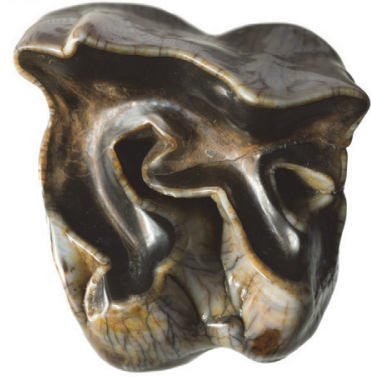

$\mathrm{L}$

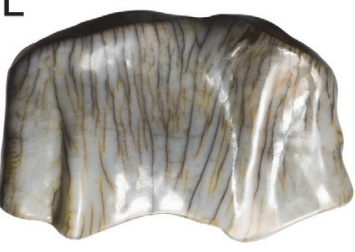

M

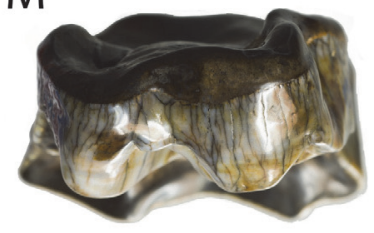

$\mathrm{N}$

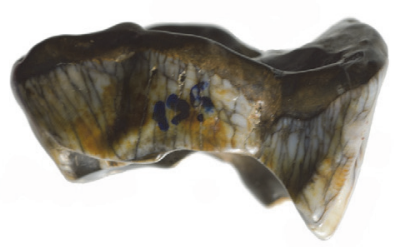

0

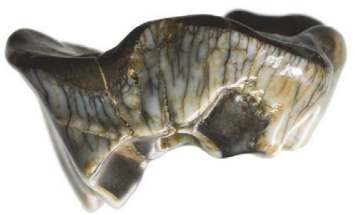

FIGURE 4. Upper molars of Stephanorhinus hundsheimensis from Bogovina Cave: right M1/M2 HMP-131 in (A) occlusal, (B) vestibular, (C) lingual, (D) mesial and (E) distal views; right M1/M2 HMP-X in (F) occlusal, $(G)$ vestibular, $(H)$ lingual, (I) mesial and (J) distal views; left M1/M2 HMP-135 in (K) occlusal, (L) vestibular, (M) lingual, (N) mesial, and (O) distal views. 
appears remarkably brachydont. The outlet of the interior valley displays a classic V-shape in lingual view. In vestibular view, the crown is slightly rough and shows some vertical and subvertical greyish lines. These lines may also be present in other portions of the crown, but they are not visible due to the manganese coating. Cingula are present on the bases of both the protocone and the hypocone, mesial and distal sides; the horizontal lingual cingulum continues as a prominent oblique mesial cingulum.

A right M1 or M2, specimen HMP-X (Figure $4 \mathrm{~F}-\mathrm{J}$ ) presents a rather complete but worn crown, with very little preserved of the roots; grey enamel is heavily yellow-stained (iron oxides), showing regions with manganese coating. The specimen displays only minimal taphonomic smoothing, confined mostly to the damaged roots. The occlusal view shows a trapezoidal-shaped crown typical for upper molars. Despite being obscured by the localised enamel damage, the presence of a paracone fold on the ectoloph profile is evident. A single crochet is present, and there is an open medisinus and a distinct postfossetta. The occlusal morphology does not include the presence of an antecrochet or crista. The protocone is markedly constricted. The cingulum can be observed on lingual, mesial, and distal (around the base of the metastyle) sides.

The specimen HMP-135 (Figure 4K-O) is a left M1 or M2 consisting of a well-preserved and complete crown without roots, showing pro- nounced wear and grey-coloured, iron-oxide stained enamel. The crown shows rounded and polished surfaces (indicating water transport). A trapezoidal shape can be observed in occlusal view. The ectoloph profile displays a distinct, strong paracone fold. There is a relatively large single crochet, an open medisinus and the postfossetta. There is no antecrochet or crista. The base of the protoloph is rather bulbous, which is more evident in the lingual view; there is a strong constriction of the protocone. The outlet of the lingual valley shows an enlarged $V$-shape in lingual view. The enamel surface shows the presence of a large number of vertical and subvertical greyish-brownyellow lines. A small portion of a mesial cingulum can be seen under the protocone constriction, and also on the distal side (smoothed via taphonomic processes). The tooth appears rather brachydont.

The specimen HMP-136 (Figure 5A-B) is a right $\mathrm{M} 1$ or $\mathrm{M} 2$, and it consists of a damaged crown, with vestibular part (ectoloph) and roots missing; the tooth has light brown colouration, different from other specimens reported in this paper. However, like some other specimens (HMP-131 and $\mathrm{X}$ ), the mesial parts of the crown under the cingulum display black manganese staining. Despite damage, the trapezoidal crown outline is obvious. The wear is not pronounced, so many details of the occlusal morphology can be assessed. There is a rather strong crista and a large crochet; there is also a small second crista located between the crochet and the crista. The medisinus is open. Only a
A

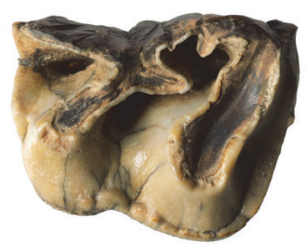

B

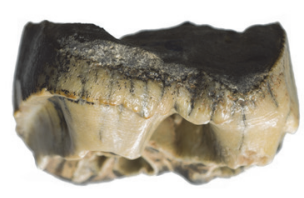

C

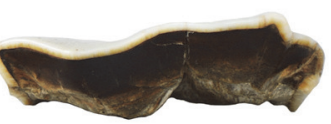

E

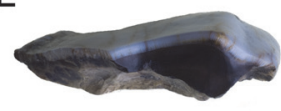

D

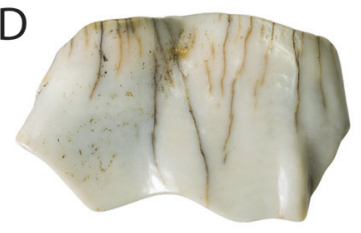

F
G
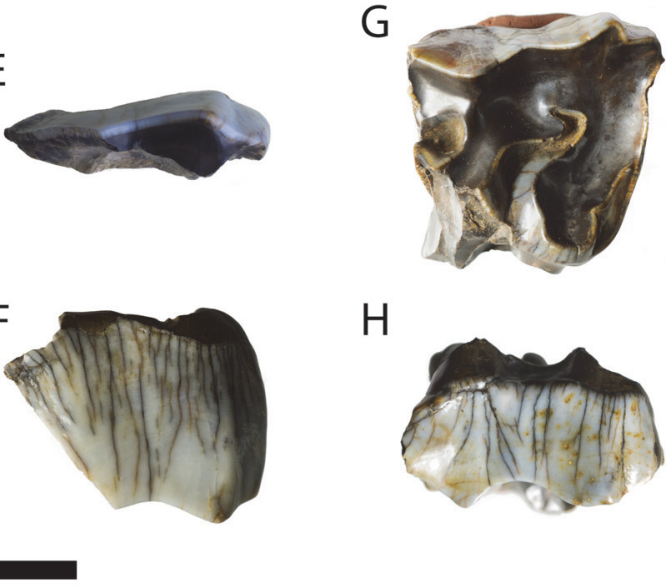

$\mathrm{H}$

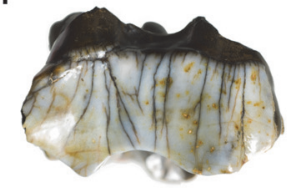

\section{$5 \mathrm{~cm}$}

FIGURE 5. Fragmented upper teeth of Stephanorhinus hundsheimensis from Bogovina Cave: right M1/M2 HMP-136 in (A) occlusal and (B) lingual views; right M HMP-132 in (C) occlusal and (D) vestibular views; right M HMP-134 in (E) occlusal and $(F)$ vestibular views; right DP4 HMP-130 in $(G)$ occlusal and $(H)$ vestibular views. 
hint of an antecrochet can be observed. The postfossetta is marked. The protocone is only very lightly constricted and bulbously inflated. A horizontal cingulum is present on the lingual, distal, and mesial sides; the mesial cingulum presents a very prominent and sharp, continuous and oblique protuberance.

The fossil designated HMP-132 (Figure 5C-D) represents only a vestibular right upper molar crown fragment with grey-coloured, smooth and polished enamel, showing several vertical and subvertical brown to yellow lines. The ectoloph profile bears a strong paracone fold. A part of the distal cingulum is preserved at the base of the metastyle.

The specimen HMP-134 (Figure 5E-F) is a mesial half of the vestibular crown fragment of a larger right upper molar. The smooth and polished grey-coloured enamel displays many vertical and subvertical brown to yellow lines. A marked paracone fold is present.

The specimen HMP-130 (Figure $5 \mathrm{G}-\mathrm{H}$ ) is a right upper deciduous tooth, probably a DP4. It consists of a very worn and damaged crown, with grey-bluish enamel with iron-oxide stains. The most damaged regions of the crown are the metacone and the hypocone; the roots are mostly missing, and only the lingual ones are preserved to some length. The crown shows a trapezoidal shape in occlusal view, with the distal side shorter than the medial one; the ectoloph profile is rather well marked (despite the damage to its mesial and distal portions), showing a strong paracone fold. The occlusal surface is smooth and polished (shiny), showing the lingual valley and the postfossetta, an open medisinus, and a single, quite massive crochet. The protocone, characterised by a pronounced constriction, appears remarkably bulbous. Unfortunately, the hypocone has been broken off. The enamel surface presents several vertical and subvertical brown lines. The cingulum can be seen on the preserved mesial side.

Lower dentition: The fossil designated HMP-129 (Figure 6A-E) is a right $\mathrm{m} 1$ or $\mathrm{m} 2$, and it represents a perfectly preserved yellow-grey-coloured crown with mild wear, without roots. In occlusal view the crown shows a distinct paralophid and a welldefined mesial valley (i.e., trigonid basin); the mesial valley is narrower than the distal one, and both of them show a V-shape outline in lingual view. The opening of the vestibular syncline is right-angled. Oblique and continuous mesial and distal cingula are present (with interproximal wear), and they continue partially on the vestibular side.
A right $\mathrm{p} 3$ or $\mathrm{p} 4$ designated HMP-407 (Figure $6 \mathrm{~F}-\mathrm{J}$ ) preserves a complete worn crown and partial roots. The enamel is mostly yellow to brown, due to iron-oxide staining. This specimen does not show taphonomically induced rounding or polishing. It displays a relatively small mesial valley and a larger distal one, both with V-shaped outlines in the lingual view, and a right-angled vestibular syncline. Mesial and distal cingula (oblique and continuous) are evidently present, though obscured by interproximal wear; a faint, horizontal and discontinuous cingulum is present on the vestibular side of the crown as well.

A right p2 known as HMP-139a (Figure 6K-O) represents a small-sized, yellow-grey crown in an excellent state of preservation, with only a mild degree of occlusal wear in its mesial portion; roots are missing. The crown displays a much reduced paralophid and metalophid, a well-developed hypolophid, a well-defined, lingually $\mathrm{V}$-shaped, distal valley (i.e., talonid basin), a wide and rightangled opening of the vestibular syncline, and gracile mesial and distal cingula (the latter is reduced due to interproximal wear).

\section{Metric Data}

Dimensions for the well-preserved specimens are provided in Table 1. The comparative data (length and width ranges) are provided in Table 2. When regarded as $P 3$, the specimen NMKVRS.P13 is within the reported ranges for Stephanorhinus etruscus, S. hundsheimensis, S. hemitoechus, and narrower and (only marginally) shorter than S. kirchbergensis P3. When regarded as P3, however, NMKVRS.P13 is smaller (shorter and narrower) than S. kirchbergensis $\mathrm{P} 4$, marginally shorter than S. hemitoechus P4 and marginally narrower than $S$. hundsheimensis $\mathrm{P} 4$. The upper molar HMP-X is shorter than S. kirchbergensis M1, while within the ranges for M1s of other taxa; HMP$X$ is within the ranges for most of the $M 2$ comparative taxa, albeit smaller than S. kirchbergensis M2 and below the width range reported for $S$. hemitoechus M2. The HMP-131 molar falls within the ranges for all the comparative taxa, both when viewed as $M 1$ and $M 2$, with a notable exception of being somewhat longer than $S$. etruscus $\mathrm{M} 1$. The HMP-135 upper molar fits the M1 and M2 data for three species (S. etruscus, S. hundsheimensis, S. hemitoechus), while being narrower than $S$. kirchbergensis $\mathrm{M} 1$, and smaller (in both dimensions) from S. kirchbergensis M2. The HMP-130 deciduous upper tooth is narrow relative to the (permanent) molars of all the comparative groups. 
A

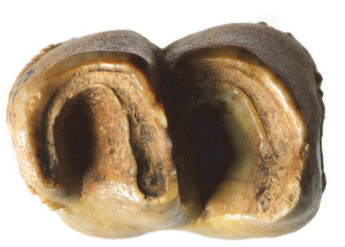

B

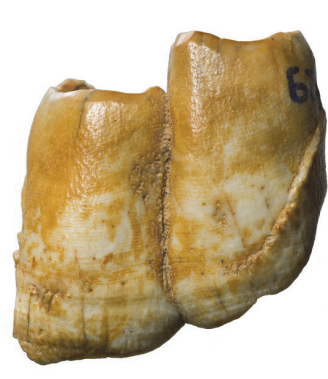

C
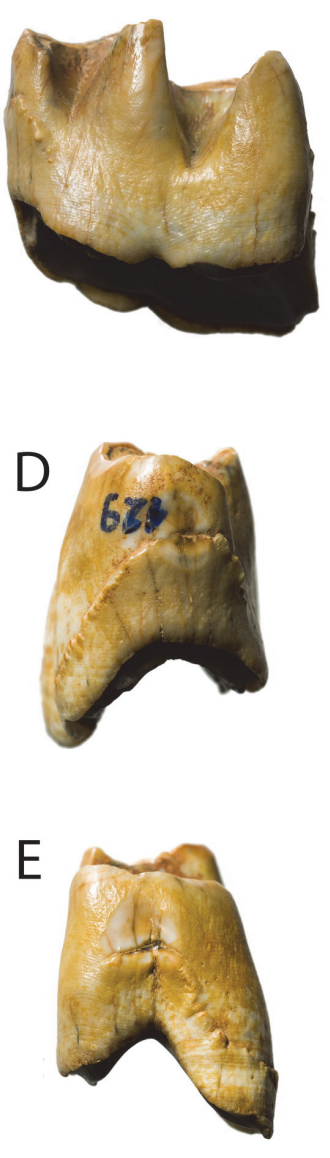

$\mathrm{F}$

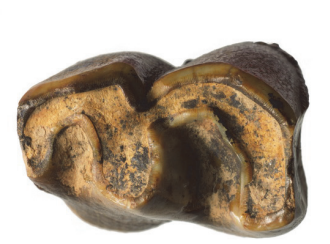

G

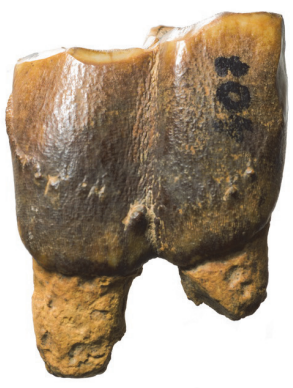

$\mathrm{H}$
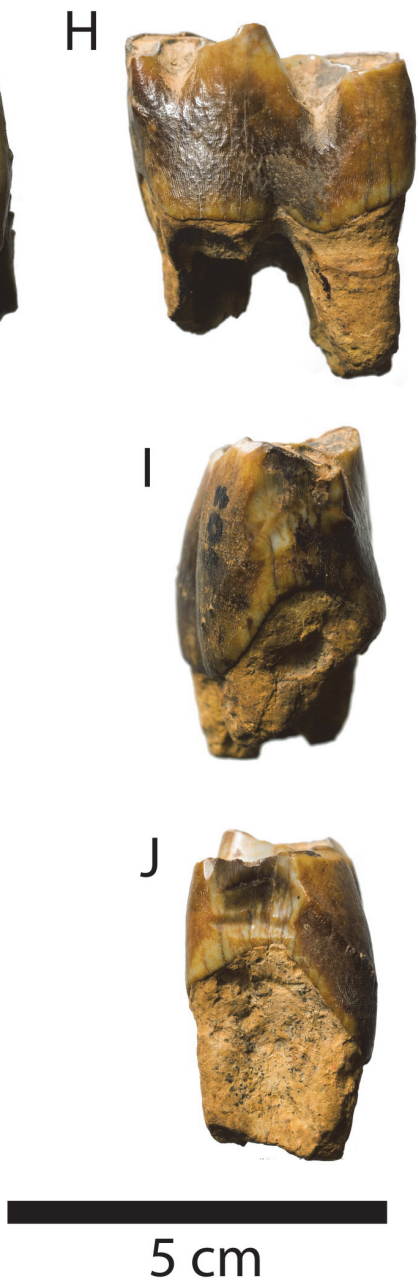

K

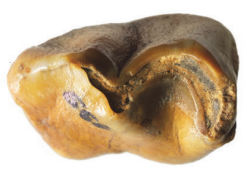

$\mathrm{L}$

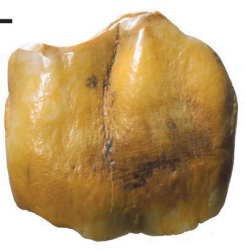

M

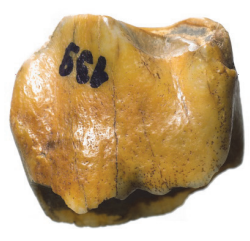

$\mathrm{N}$

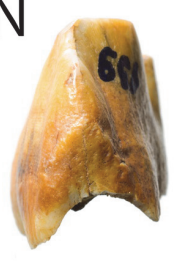

$\mathrm{O}$

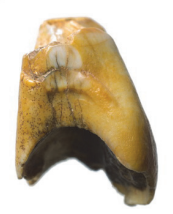

FIGURE 6. Lower teeth of Stephanorhinus hundsheimensis from Bogovina Cave: right m1/m2 HMP-129 in (A) occlusal, (B) vestibular, (C) lingual, (D) mesial and (E) distal views; right p3/p4 HMP-407 in (F) occlusal, (G) vestibular, (H) lingual, (I) mesial and (J) distal views; right p2 HMP-139a in (K) occlusal, (L) vestibular, (M) lingual, (N) mesial, and (O) distal views. 
TABLE 1. Dimensions (in $\mathrm{mm}$ ) of the rhinoceros teeth from Bogovina Cave (Serbia). Abbreviations: $L=$ vestibular length; $W=$ mesial width. Asterisks indicate damaged specimens; the actual dimensions are greater than the measured values.

\begin{tabular}{cccc}
\hline Specimen & Tooth & L & W \\
\hline NMKVRS.P13 & left P3/P4 & 37.8 & 48.3 \\
HMP-139b & right P3/P4 & - & $>52^{*}$ \\
HMP-130 & right M1/M2 & $>41.2^{*}$ & 41.9 \\
HMP-131 & right M1/M2 & 54.0 & 59.2 \\
HMP-X & right M1/M2 & 47.5 & 52.7 \\
HMP-135 & left M1/M2 & 49.8 & 55.0 \\
HMP-139a & right p2 & 31.5 & 20.5 \\
HMP-407 & right p3/p4 & 37.2 & 26.8 \\
HMP-129 & right m1/m2 & 43.0 & 30.6 \\
\hline
\end{tabular}

TABLE 2. Dental measurements (ranges, in $\mathrm{mm}$ ) of four Stephanorhinus species; data from Fortelius et al. (1993), Guérin (1980), Handa and Pandolfi (2016), Pandolfi and Erten (2017) and Pandolfi and Marra (2015). Abbreviations: L = vestibular length; $\mathrm{W}=$ mesial width.

\begin{tabular}{|c|c|c|c|c|c|}
\hline Tooth & Measurement & $\begin{array}{c}\text { S. etruscus } \\
\text { range (min. - max.) }\end{array}$ & $\begin{array}{l}\text { S. hundsheimensis } \\
\text { range (min. - max.) }\end{array}$ & $\begin{array}{c}\text { S. hemitoechus } \\
\text { range (min. - max.) }\end{array}$ & $\begin{array}{l}\text { S. kirchbergensis } \\
\text { range (min. - max.) }\end{array}$ \\
\hline \multirow[t]{2}{*}{ P3 } & $L$ & $31-41$ & $32-46$ & $34-43$ & $38-51.8$ \\
\hline & W & $42-55$ & $45-57.5$ & $44-53$ & $50-64$ \\
\hline \multirow[t]{2}{*}{ P4 } & L & $34-44$ & $35-48.5$ & $38-48$ & $40-53$ \\
\hline & W & $45-63$ & $50-62$ & $47-62$ & $56-73$ \\
\hline \multirow[t]{2}{*}{ M1 } & L & $41-53$ & $42-57.5$ & $42-57.5$ & $47.2-63.5$ \\
\hline & W & $48-62$ & $51-65$ & $53-68$ & $60-74$ \\
\hline \multirow[t]{2}{*}{ M2 } & L & $45.5-57$ & $47-63$ & $46.5-65$ & $50-69.6$ \\
\hline & W & $48-65.5$ & $52-67$ & $56-72$ & $62-77.1$ \\
\hline \multirow[t]{2}{*}{ p2 } & L & $25-36.4$ & $25.2-39$ & $23-31$ & $26-34$ \\
\hline & W & $16-21.5$ & $16-33$ & $14.5-21$ & $19-21.5$ \\
\hline \multirow[t]{2}{*}{ p3 } & L & $31.3-39.7$ & $30-42.5$ & $27-40$ & $35-46$ \\
\hline & W & $21.5-30$ & $21-37$ & $21-28$ & $27-35.5$ \\
\hline \multirow[t]{2}{*}{$\mathrm{p} 4$} & L & $34.4-43$ & $33-45$ & $35-43$ & $38-51$ \\
\hline & W & $24-31$ & $23-35$ & $24-32$ & $28.5-38.5$ \\
\hline \multirow[t]{2}{*}{$\mathrm{m} 1$} & L & $35.2-49$ & $37-57$ & $36.5-52$ & $43-59$ \\
\hline & W & $26-33$ & $25-37$ & $26-35$ & $33-42$ \\
\hline \multirow[t]{2}{*}{$\mathrm{m} 2$} & $\mathrm{~L}$ & $40-49$ & $39-57.5$ & $41-55$ & $53-63$ \\
\hline & W & $25-33.5$ & $23.5-35$ & $28-36$ & $32-40$ \\
\hline
\end{tabular}

The HMP-139a lower second premolar is within the ranges of all taxa, except being marginally longer than Stephanorhinus hemitoechus p2. The specimen HMP-407 is within the ranges for most taxa both when viewed as p3 and p4; it only differs from $S$. kirchbergensis by being marginally narrower when viewed as $\mathrm{M} 1$, and by being narrower and marginally shorter when viewed as M2. Finally, the lower first or second molar HMP-129 is within the reported ranges for most groups, both when viewed as $\mathrm{m} 1$ and $\mathrm{m} 2$; however, this molar is narrower than $S$. kirchbergensis $\mathrm{m} 1$, and smaller (shorter and narrower) than S. kirchbergensis m2.

\section{The Accompanying Mammalian Fauna}

In addition to the rhinoceros material, dental remains of other Pleistocene large mammals were also collected from the site, including horse (Equus sp.) and an indeterminate bovid. These additional specimens display shiny, brown and black surfaces, which could indicate that the fossils originated from the same stratigraphic context as many 

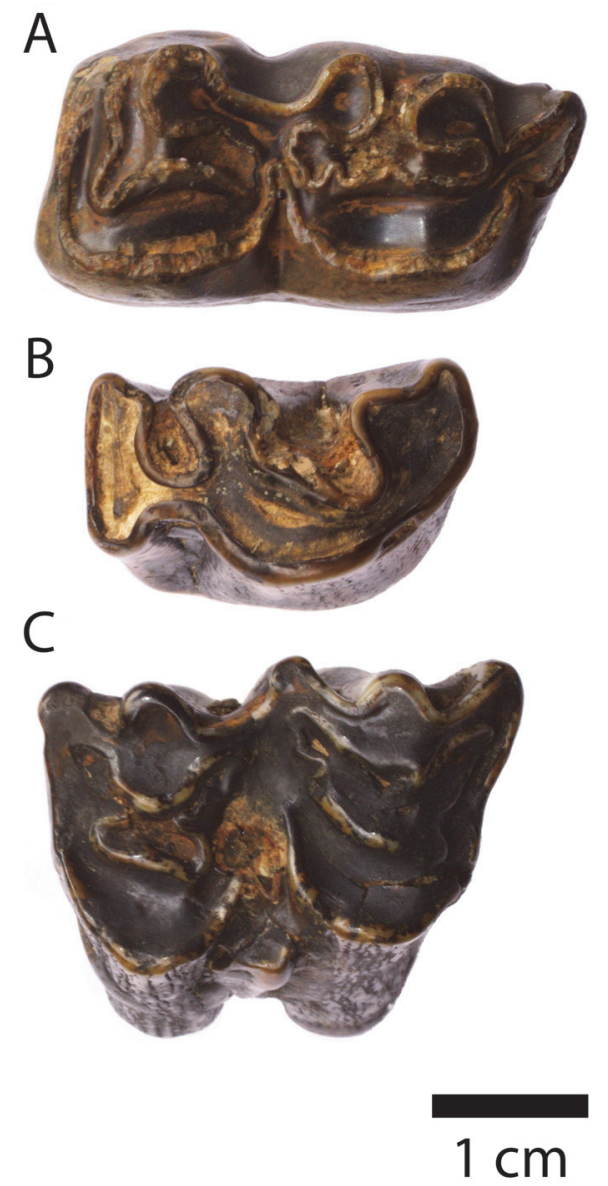

FIGURE 7. Equid and bovid dental specimens from Bogovina Cave: left lower molar of a caballoid horse NMKVRS.P12 in (A) occlusal view; indeterminate bovid right p4 NMKVRS.P14 in (B) occlusal view; indeterminate bovid left M1/M2 NMKVRS.P15 in (C) occlusal view.

of the rhinoceros teeth (e.g., HMP-130, 139b). However, different stratigraphic provenance cannot be excluded.

The equid (Equidae) material consists of an isolated left lower molar ( $\mathrm{m} 1$ or $\mathrm{m} 2$ ) NMKVRS.P12 (Figure 7A). The genus Equus may be separated into two different lineages: the stenonid (zebroid) and the caballoid (true) horses. The most obvious dental differences between the two groups can be seen in the lower cheek teeth, namely, in the morphology of the metaconid-metastylid loops (the double knot) and in the shape of the entoflexids (i.e., linguaflexid sensu Skinner et al., 1972) (Forstén, 1992). Stenonid lower premolars and molars are characterised by the V-shaped entoflexid, and concave protoconids and hypoconids; conversely, caballoids show U-shaped entoflexid with straight protoconids and hypoconids, and a rounded metaconid (Arceredillo, 2008). As seen in Figure 7A, the specimen from Bogovina Cave clearly shows U-shaped entoflexid, thus indicating a caballoid horse. Furthermore, the size of molar ( $\mathrm{L}$ $=33.8 \mathrm{~mm}, \mathrm{~W}=14.7 \mathrm{~mm}$; measured at the occlusal surface, excluding cement) is comparable to the large-sized group of caballoid horses of Forstén and Dimitrijević (2004), well-known from the caves and rock shelters of the Central Balkans. Indeterminate bovid (Bovidae) dental specimens were also discovered: a right permanent lower fourth premolar (p4) NMKVRS.P14 (Figure 7B; L = $25.3 \mathrm{~mm}, \mathrm{~W}=16.8 \mathrm{~mm}$ ) and a left upper molar (M1 or M2) NMKVRS.P15 (Figure $7 \mathrm{C}$; L = $31.5 \mathrm{~mm}, \mathrm{~W}$ $=20.5 \mathrm{~mm}$ ). We did not attempt to classify these two isolated specimens at genus and species levels, due to the well-known fact that large bovine teeth show great variability of proportions and structures (Sher, 1997).

\section{DISCUSSION AND CONCLUSION}

The genus Stephanorhinus Kretzoï, 1942, comprises several extinct rhinoceros species that lived in the Palaearctic region during the Neogene to Quaternary. All members of the genus were dolichocephalic, two-horned rhinoceroses, with pronounced molarization of premolars and with no functional incisors Fortelius et al., 1993. The Hundsheim rhinoceros, Stephanorhinus hundsheimensis Toula, 1902, represents one of the four species of the genus Stephanorhinus that existed in the European Pleistocene (see Figure 8), along with the Etruscan rhinoceros, S. etruscus Falconer, 1868 from the Early Villafranchian to Early Galerian (i.e., latest Pliocene to Early-Middle Pleistocene transition; Pandolfi et al., 2017a), the narrownosed rhinoceros, S. hemitoechus Falconer, 1859 from the Middle Galerian and Aurelian (i.e., Middle to Late Pleistocene; Guérin, 1980; Stuart and Lister, 2007, 2012; Pandolfi et al., 2013; Pandolfi et al., 2017b), and the Merck's rhinoceros, S. kirchbergensis Jäger, 1839 from the Middle Galerian and Aurelian (i.e., Middle to Late Pleistocene; Pandolfi and Marra, 2015). According to Guérin (1980), S. hundsheimensis (syn. Dicerorhinus etruscus brachycephalus) and $S$. hemitoechus both evolved from the species $S$. etruscus, but others (Fortelius et al., 1993; Lacombat, 2007) link S. hundsheimensis with the species $S$. jeanvireti from the European Late Ruscinian-Early Villafranchian (i.e., Late Pliocene; Lacombat, 2007; Ros-Montoya et al., 2017). Another hypothesis (Mazza, 1988; Van der Made, 2000) sees S. hundsheimensis as an Asian migrant. The evolutionary origin of the Hundsheim 


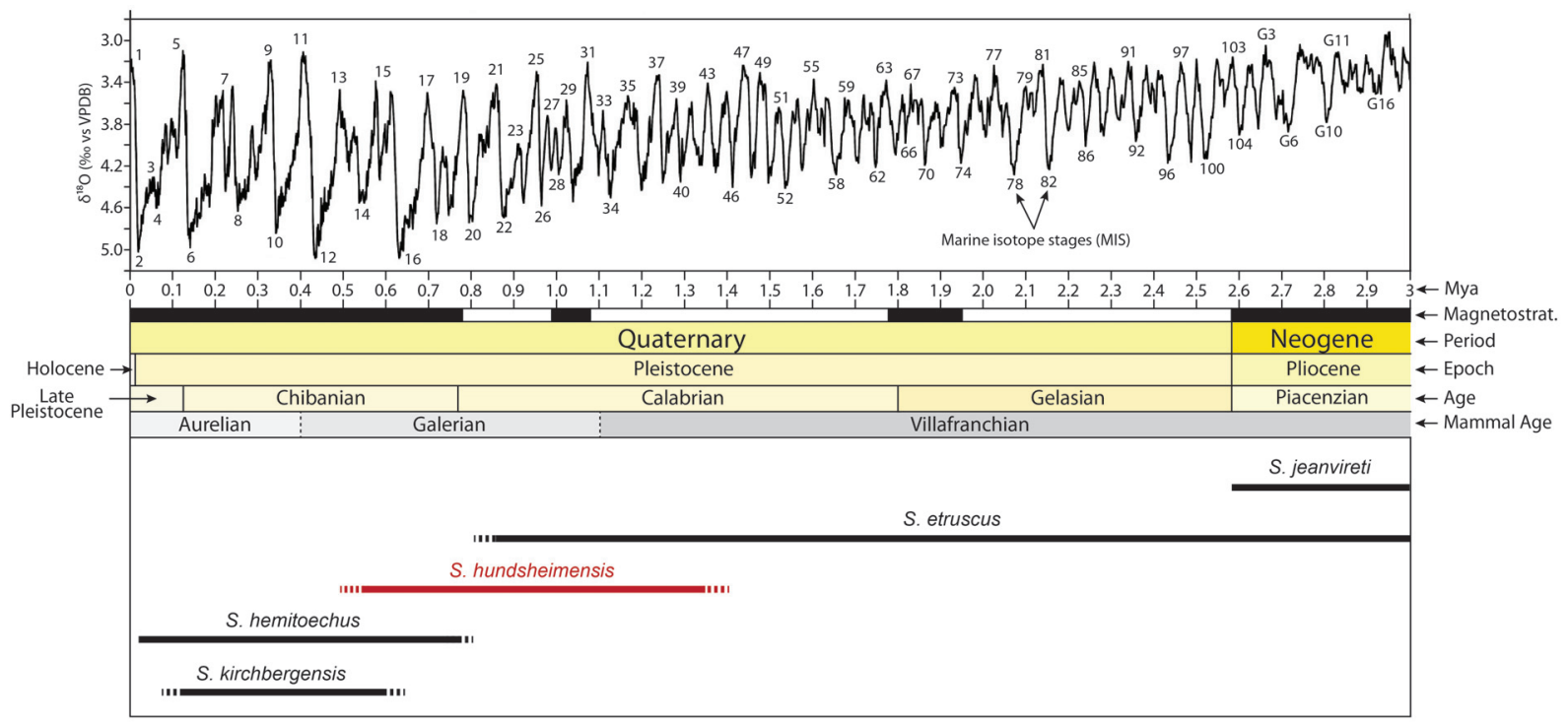

FIGURE 8. Chronological and biochronological ranges of the four Stephanorhinus species known from the territory of Europe. Marine isotope stages according to Lisiecki and Raymo (2005).

rhinoceros remains unresolved, as does the more general issue of the phylogenetic relationships within the genus Stephanorhinus. Moreover, the genus Stephanorhinus is probably paraphyletic as currently defined, which is indicated both by the morphological (Pandolfi et al., 2015, 2016) and molecular (Cappellini et al., 2019) data. The analysis of dental enamel proteome of an isolated lower molar classified as Stephanorhinus ex gr. etruscushundsheimensis from the $1.77 \mathrm{Myr}$ old site of Dmanisi (South Caucasus, Georgia) conducted by Cappellini et al. (2019) demonstrated that this individual represents a sister group to the clade formed by Coelodonta antiquitatis and S. kirchbergensis, implying that the genus Stephanorhinus includes at least two distinct evolutionary lines thus urging for a systematic revision of the genus.

According to Kahlke and Kaiser (2011), Stephanorhinus hundsheimensis was a long-legged rhino with cursorial limb proportions and a head posture which allowed it to feed both as a grazer and browser on the vegetation of intermediate height. A reconstruction of $S$. hundsheimensis with its calf in its hypothetical palaeoenvironment (after Gianfranco Mensi, 2015) is proposed here in Figure 9. Based on the pollen content of sediment adhering to skeletal elements of large fauna from the approximately 1.8 to $1.1 \mathrm{Ma}$ old lacustrine basin succession of Leffe (Italian Alps), S. etruscus-hundsheimensis was associated with different palaeoenvironmental conditions, ranging from a warm-temperate climate with dense mixed forest to conifer forest to cold-temperate climate with open xerophytic communities and steppe with birch trees (Betula sp.) and sparse woodland patches (Ravazzi et al., 2009). Recently, Szabó et al. (2017) had evaluated the Leffe palaeoenvironment using stable carbon and oxygen isotope compositions of rhinoceros tooth enamel, and their results indicated an open woodland-xeric grassland environment. This is in accordance with the mesowear study by Kahlke and Kaiser (2011), which revealed S. hundsheimensis as the most ecologically tolerant rhinoceros of the Palaearctic Plio-Pleistocene, with an extreme dietary variability (ranging from a grazing regime to one of predominantly browsing). Though successful over a long period time in the western Palaearctic, S. hundsheimensis finally became extinct around 0.6-0.5 Ma (but see Guérin et al., 1992), possibly due to the bilateral competition with the strict browser $S$. kirchbergensis and the specialised grazer S. hemitoechus (Kahlke and Kaiser, 2011). However, it must be noted that there is no direct evidence for coevality of $S$. hemitoechus and $S$. hundsheimensis (see Pandolfi et al., 2013), so the presumed competition between the two species likely did not contribute to the demise of $S$. hundsheimensis. Often misidentified with other Pleistocene rhinoceros taxa (e.g., $S$. etruscus, S. kirchbergensis), S. hundsheimensis is also known under several other synonyms: Rhinoceros hundsheimensis Toula, 1902; Rhinoceros etruscus var. heidelbergensis Freudenberg, 1914; Dicerorhinus hundsheimensis Toula, 1902; Dicer- 


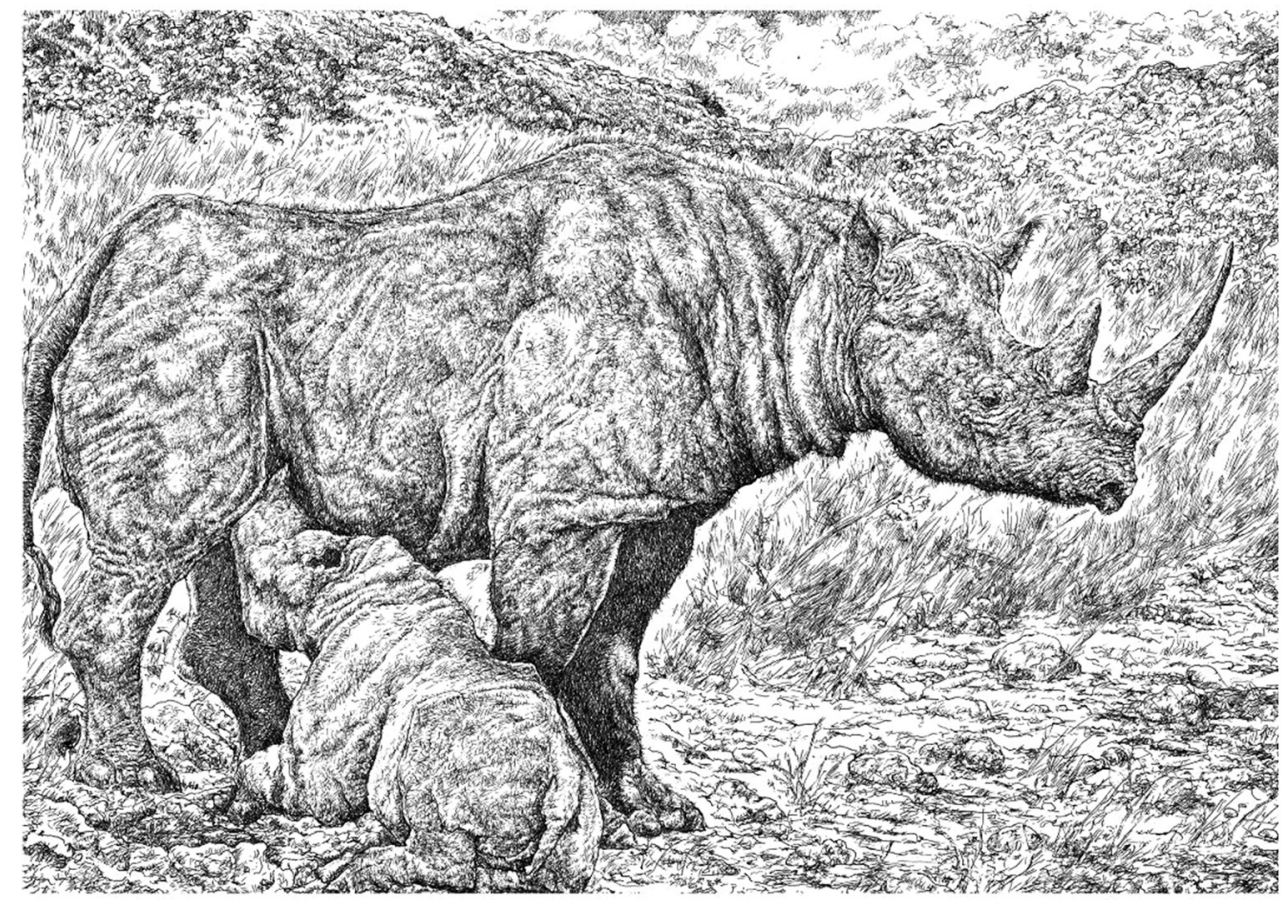

FIGURE 9. A reconstruction of Stephanorhinus hundsheimensis (Toula, 1902) with its calf in its hypothetical palaeoenvironment (after Gianfranco Mensi, 2015; this unpublished illustration is used here through the courtesy of the artist, all rights reserved).

orhinus handzellensis Wang, 1928; Dicerorhinus hemitoechus intermedius Cigala-Fulgosi, 1976; Dicerorhinus etruscus brachycephalus Guérin, 1980. Having widely been discussed by several authors (e.g., Guérin, 1980; Fortelius et al., 1993; Lacombat, 2006a, 2006b, 2007; Pandolfi and Erten, 2017), the geographical origin, history, general characters, and distinguishing anatomical and odontological features of $S$. hundsheimensis are not treated in the present paper.

Due to the substantial intraspecific differences and, conversely, interspecific likenesses, it is sometimes difficult to discriminate between different species of the Stephanorhinus genus. However, dental material is sometimes particularly useful in this regard, showing diagnostic traits for different species (e.g., Guérin, 1980; Fortelius et al., 1993; Lacombat, 2005, 2006a; Billia, 2007, 2008, 2011; Van der Made, 2010; Pandolfi and Marra, 2015; Pandolfi and Erten, 2017; Pandolfi et al., 2017b). Moreover, teeth (as enamel-coated structures) have high preservation potential, making them more frequent and better preserved relative to the other skeletal elements.

The teeth from Bogovina Cave are clearly brachydont, as expected for Stephanorhinus hundsheimensis (Guérin, 1980; Fortelius et al., 1993; Lacombat, 2007). In terms of size, most of the specimens fit the metric data reported for $S$. hundsheimensis. As expected for a deciduous specimen, HMP-130 is small (narrow) relative to Stephanorhinus permanent upper molars. The crochet in S. hundsheimensis upper premolars is variable (absent, single, double, triple, or more), but it is always present (single, rarely double) in upper molars (Lacombat, 2006a; Ballatore and Breda, 2013). Single crochet can be observed in HMP136b, while NMKVRS.P13 lacks the trait; as far as the molars are concerned, a distinct single crochet is present in the upper permanent molars from Bogovina Cave (HMP-X, 135, 136), as well as in the deciduous tooth HMP-130. Though generally frequent in the upper teeth of the Hundsheim rhinoceros (Lacombat, 2007), the crista is variable in P3, P4, M1, M2, and M3 (single, double, multiple, or absent), being consistently present only in P2 (Ballatore and Breda, 2013). The crista is completely absent in both upper premolars and two upper molars (HMP-X and HMP-135) from Bogovina Cave; however, other molars show either a very shallow (HMP-131) or a strong (HMP-136) single crista. As in other Stephanorhinus species, the antechrochet is usually absent in the upper molars of S. hundsheimensis (with the exception of M3), but a single antecrochet can also be present (Lacombat, 2006a). The majority of upper molar 
specimens from Bogovina Cave show no development of antecrochet whatsoever, with the exceptions of HMP-131 and HMP-136, which show only shallow expressions of the trait. In the upper premolars of $S$. hundsheimensis the antecrochet is mainly absent (Lacombat, 2006a), as is in both upper premolars from Bogovina Cave. According to Ballatore and Breda (2013) the paracone fold is generally strong in upper molars and weak (but present) in upper premolars of $S$. hundsheimensis. Moreover, the paracone fold is more developed in S. hundsheimensis than in S. etruscus (Lacombat, 2007). Invariably, a marked paracone fold can be observed in all upper molars from Bogovina Cave, which preserve the vestibular portion of the crown. Although hard to assess in the premolars, due to the wear (NMKVRS.P13) or damage (HMP-139b), a weak expression of the trait seems to be present in both cases. Highly variable (and thus non-diagnostic) for the Stephanorhinus upper molars, protocone constriction is absent (or rarely present, but very weak) in the upper premolars of $S$. hundsheimensis (Lacombat, 2006a; Ballatore and Breda, 2013). As expected, the molars from Bogovina Cave display variable expressions of protocone constriction (weak in HMP-136, and strong in HMP-X and HMP-135); the deciduous specimen HMP-130 also shows strong protocone constriction. Similar to $S$. hundsheimensis premolars, protocone constriction is absent to (possibly) very weak in NMKVRS.P13 and HMP-136b, respectively. The medisinus is always open in the upper dentition from Bogovina Cave, and one premolar (NMKVRS.P13) shows a medifossetta (i.e., feature resulting from the fusion between crochet and crista; Antoine, 2002). The angle between crochet and ectoloph (metacone) could only be assessed in three molars, and it is flat in two (HMP-131, 135) and obtuse in one (HMP-X). Deciduous HMP-130 displays a flat angle between the crochet and the ectoloph. In the M1/2 sample from Isernia $\mathrm{La}$ Pineta, this angle can be both flat and obtuse (Ballatore and Breda, 2013). The angle between crochet and metaloph is mostly obtuse in the upper molars (HMP-135, 136, X) and deciduous upper tooth HMP-130, but the angle is right in one molar (HMP-131); the upper premolar HMP-136b also shows an obtuse crochet/metaloph angle. This fits well with the Isernia La Pineta sample, in which the angle between crochet and metaloph in M1/M2 is generally obtuse or sometimes right-angled, in P3 it is generally right-angled, and in P4 it is generally obtuse, though sometimes right-angled (Ballatore and Breda, 2013). Regarding cingula, the upper teeth from Bogovina Cave are in agreement with the distribution reported by Lacombat (2006a) for Stephanorhinus hundsheimensis. As expected (Lacombat, 2006a), no cingula are observed on vestibular sides of the teeth. The lingual cingulum is present in both upper premolars, which is characteristic for $S$. hundsheimensis according to Lacombat (2006a); it is also present in three molars (HMP-131, X, 136), but absent in two (HMP-135, 130). Furthermore, both the mesial and distal cingula are found in four molars (HMP-131, $X, 135,136)$; the mesial alone can be seen in the deciduous HMP-130, and the molar fragment HMP-132 shows a part of the distal cingulum.

The morphology of the lower dentition from Bogovina Cave is for the most part in agreement with the characterisation provided by Lacombat (2006a, 2007). According to Lacombat (2007), the mandibular premolars of Stephanorhinus hundsheimensis display V-shaped valleys (although the distal valleys can be broad $V$-shaped), while mandibular molars display V-shaped to broad V-shaped mesial valleys and broad V-shaped to U-shaped distal valleys. The HMP-407 lower premolar shows a V-shaped mesial and broad V-shaped distal valley (although this trait is hard to assess due to the high degree of wear). The lower second premolar HMP-139a displays a V-shaped distal valley. The HMP-129 m1/m2 shows V-shaped mesial and distal valleys. The openings of vestibular synclines in all three specimens are wide, about right-angled. Continuous mesial and distal cingula are present in HMP-407 and HMP-129, as expected for the p3/p4 and $\mathrm{m} 1 / \mathrm{m} 2$ of $S$. hundsheimensis (Lacombat, 2006a; Ballatore and Breda, 2013). The lower p2 from Bogovina also shows both mesial and distal cingula; although Lacombat (2006a) regarded the mesial cingulum to be absent from the lower p2 in all the Pleistocene species of the genus Stephanorhinus, Ballatore and Breda (2013) found it to be present in the p2 sample of $S$. hundsheimensis from Isernia La Pineta. Additionally, the lower teeth from Bogovina Cave invariably show the presence of a discontinuous vestibular cingulum, which is again reminiscent of the Isernia La Pineta sample.

Overall, the analysis suggests that the rhinoceros dentition - belonging to two or more distinct individuals - from Bogovina Cave can be ascribed to the species Stephanorhinus hundsheimensis Toula, 1902, and we found no compelling reason to classify any of the specimens differently. Features of the upper premolars (no antecrochet; weak paracone fold; absent or very weak protocone constriction; lingual cingulum present), the upper 
molars (single crochet; variable crista; marked paracone fold; absent to shallowly expressed antecrochet; mesial and lingulal cingula; no medifossetta; weak to strong protocone constriction), the deciduous premolar (no crista; no antecrochet; no medifossetta; protocone constriction present), and the lower premolars and molars (V-shaped mesial and distal valleys; present mesial and distal cingula) are all in accordance with our taxonomic attribution. Therefore, the material from Bogovina Cave represents, to our knowledge, the first find of the Hundsheim rhinoceros in Serbia, and (together with the woolly rhinoceros) the second Pleistocene rhinoceros species discovered in Serbia. Geographically, the closest record of $S$. cf. hundsheimensis comes from Layers 5 and 6 of Trlica near Pljevlja in northern Montenegro (Dimitrijević, 1990, 1996; Codrea and Dimitrijević, 1997). Based on the finds of small mammals, Layers 5 and 6 were correlated with the Mimomys savini-pusillus Zone of the Early Pleistocene by Bogićević and Nenadić (2008), while Vislobokova and Agadjanyan (2016) dated these layers to post-Villafranchian times (i.e., the early phase of the Middle Pleistocene, MIS 19). In addition, Vislobokova and Agadjanian (2015) reported a few more isolated rhinoceros teeth from the lower levels (Layers 10 and 11) at Trlica, and identified them as S. etrusctus; according to Pandolfi et al. (2017a), however, these specimens morphologically resemble $S$. hundsheimensis. Vislobokova and Agadjanyan (2016) correlated Layers 10 and 11 with the second half of the Early Pleistocene (i.e., Late Villafranchian, MNQ 18 zone). The Southeastern European record also includes the fossils from the Galerian site of Subpiatră in Romania (Codrea and Czier, 1991), and from the latest Villafranchian sites of Platanochori1 and (possibly) Apollonia in Greece (Konidaris et al., 2015). S. hundsheimensis (or S. cf. hundsheimensis) is known from numerous other sites throughout Europe and Western Asia. The species is attested in Britain (an overview is available in Breda et al., 2010) and France (various sites, e.g., Guérin, 1980; Lacombat, 2006a, 2006b, 2007). In Spain, the Hundsheim rhinoceros is reported from the Late Villafranchian sites of Fuente Nueva-3 and Barranco Léon 5 (Lacombat, 2010), Venta Micena (Santafé-Llopis et al., 1987; MadurellMalapeira et al., 2014), and possibly from El Molinar (Van der Made and Montoya, 2007). According to some authors (Cerdeño, 1993; Van der Made, 2010; Pandolfi et al., 2017a) the specimens from Venta Micena, in fact, represent $S$. etruscus. The Hundsheim rhinoceros is also pres- ent in the Italian fossil record, at Galerian sites such as Isernia-La Pineta (Ballatore and Breda, 2013), Cava Redicicoli (Marra et al., 2014), Tour de Grimaldi (Lacombat and Moullé, 2005), San Colombano al Lambro (Caccia, 1928; Cantaluppi, 1969; Persico et al., 2015), and others. Three exceptionally preserved $S$. hundsheimensis skulls come from the Castell'Arquato area (Piacenza; Monesi et al., 2016; Bona and Sala, 2016). The earliest possible record comes from the latest Villafranchian of Pietrafitta (Perugia, central Italy), ascribed to Stephanorhinus cf. hundsheimensis by Mazza et al. (1993), based mainly on the postcranial morphology; however, the Pietrafitta rhinoceros was later reassigned to $S$. etruscus by some other authors (Van der Made, 2010; Pandolfi and Petronio, 2011; Pandolfi et al., 2015; Pandolfi and Erten, 2017; Pandolfi et al., 2017a). In Germany, S. hundsheimensis is recorded at several early Middle Pleistocene sites such as Süssenborn and Voigtstedt (Kahlke, 1965, 1969; Kahlke and Kaiser, 2011), and Mauer and Mosbach 2 (Fortelius et al., 1993; Schreiber, 2005; Koenigswald et al., 2007). The holotype of the species comes from the early Middle Pleistocene site of Hundsheim in Lower Austria (Toula, 1902), while in neighbouring Slovakia, S. cf. hundsheimensis is recorded at the early Middle Pleistocene of Levický Vápnik (Zervanová, 2014). In Turkey, S. hundsheimensis is recorded in the late Early Pleistocene of Denizli Basin in Anatolia (Pandolfi and Erten, 2017). Pavlova (1925) also reported the species from Tiraspol' (at present the Pridnestrovian Moldavian Republic) as Rhinoceros etruscus var. heidelbergensis Freudenberg, 1914; however, the remains were later reassigned to Dicerorhinus etruscus (Falconer) (=Stephanorhinus etruscus [Falconer]) (Belyaeva and David, 1975). In the South Caucasus region, S. cf. hundsheimensis was reported from the latest Villafranchian site of Kurtan in Armenia (Mkrtchyan et al., 2011), and S. hundsheimensis (=Dicerorhinus etruscus brachycephalus sensu Guérin, 1980) was reported from the Acheulean layers of Kudaro-1 Cave in Georgia (Baryshnikov and Guérin, 1986). The Mousterian site of Erivan I (Armenia) is particularly important because it possibly documents a late (MNQ 26 zone) survival of the species in Caucasus (Baryshnikov et al., 1989; Guérin et al., 1992). However, the material is scarce, consisting of postcranial elements only, so the interesting scenario of the Caucasus acting as refugium cannot be confirmed.

The Hundsheim rhinoceros from Bogovina Cave can only be broadly dated to the late Early 
and early Middle Pleistocene, based on the known stratigraphic range of the species in Europe. Since the teeth show differences in colour and degrees of smoothing/polishing, they probably originated from different strata and were exposed to differential degrees of water-induced transport. As the geological context is lacking, it is very hard to hypothesise a more precise chronology of the material. Nevertheless, the find of a caballoid horse molar could be taken as potentially indicative in this regard. The earliest caballoid horses in Europe occur in the early Middle Pleistocene (Galerian), as indicated by the $600 \mathrm{ka}$ old mixed stenonid and caballoid equid assemblage from Süssenborn in Germany (Musil, 1969; Forstén, 1986). If rhinoceros dentition from Bogovina Cave (or at least some specimens) originated from the same stratigraphic horizon as the caballoid horse molar, this would suggest an age of 600 ka or less (Middle to Late Galerian). However, according to Forstén and Dimitrijević (2004) most caballoid horse fossils from the Central Balkans probably come from the Late Pleistocene. Despite the fact that caballoid horses can survive in a wide range of habitats, the presence of a caballoid molar at Bogovina Cave may also indicate a humid, closed, and cooler environment (Van Asperen et al., 2012). By contrast, the association of stenoid horses with Stephanorhinus cf. hundsheimensis at Trlica (Codrea and Dimitrijević, 1997 ) is seen as an indicator of drier, warmer, and more open landscapes (Van Asperen et al., 2012). This apparent palaeoenvironmental variability is in accordance with studies (Ravazzi et al., 2009; Kahlke and Kaiser, 2011), which pointed to the extremely wide ecological domain of the Hundsheim rhinoceros.

\section{ACKNOWLEDGEMENTS}

We are grateful to V. Vučković (Homeland Museum Paraćin, Serbia) for access to the fossil material. We would also like to thank J. van der Made (Museo Nacional de Ciencias Naturales Madrid, Spain) and N. Cvetković (Regional Museum of Jagodina, Serbia) for their useful suggestions and comments, J. Lindal (Department of Anthropology, University of Manitoba, Canada) for proofreading the paper, and $S$. Vulović and $A$. Maričić (National Museum Kraljevo, Serbia) for photographing the specimens. Thanks to the handling editors $A$. Souron and $M$. Wetherell, as well as the anonymous reviewers for their input on the initial draft.

\section{REFERENCES}

Antoine, P.-O. 2002. Phylogénie et évolution des Elasmotheriina (Mammalia, Rhinocerotidae). Mémoires du Muséum National d'Histoire Naturelle, 188:1-359.

Arceredillo, D. 2009. Morphometric differences among the equids of the Upper Pleistocene from Valdegoba (Burgos, Spain). Bulletin of the International Association for Paleodontology, 2(2):21-6.

Ballatore, M. and Breda, M. 2013. Stephanorhinus hundsheimensis (Rhinocerontidae, Mammalia) teeth from the early Middle Pleistocene of Isernia La Pineta (Molise, Italy) and comparison with coeval British material. Quaternary International, 302:169-183. https:// doi.org/10.1016/j.quaint.2013.02.002

Banješević, M. 2010. Upper Cretaceous magmatic suites of the Timok Magmatic Complex. Annales Géologiques de la Péninsule Balkanique, 71:13-22. https://doi.org/10.2298/ GABP1071013B

Baryshnikov, G.F. and Guérin, C. 1986. Ostatki nosoroga Dicerorhinus etruscus brachycephalus iz ashel'skogo sloya peshchery Kudaro 1 (Bol'shoy Kavkaz), p. 62-73. In Vereshchagin N.K. and Kuz'mina I.E. (eds.), Mleklopitayushchie Chetvertichnoy Fauny SSSR. Trudy Zoologicheskogo Instituta Akademii Nauk SSSR 149. (In Russian with English summary)

Baryshnikov, G.F., Geren, K. [Guérin, C.] and Mezhlumyan, S.K. 1989. Nosorog Dicerorhinus etruscus brachycephalus iz Erevanskoy must'erskoy stoyanki, p. 103-110. In Baryshnikov, G.F. and Kuz'mina, I.E., (eds.), Materialy po Mamontovoy Faune Severnoy Evrazii. Trudy Zoologicheskogo Instituta Akademii Nauk SSSR 198. (In Russian with English summary)

Belyaeva, E.I. and David, A.I. 1975. Die Nashörner (Rhinocerotidae) aus dem Faunenkomplex von Tiraspol. Quartärpaläontologie, 1:157-175. 
Billia, E.M.E. 2007. First records of Stephanorhinus kirchbergensis (Jäger, 1839) (Mammalia, Rhinocerotidae) from the Kuznetsk Basin (Kemerovo region, Kuzbass area, South-East of Western Siberia). Bollettino della Società Paleontologica Italiana, 46(2-3):95-100.

Billia, E.M.E. 2008. Revision of the fossil material attributed to Stephanorhinus kirchbergensis (Jäger, 1839) (Mammalia, Rhinocerotidae) preserved in the museum collections of the Russian Federation. Quaternary International, 179:25-37. https://doi.org/10.1016/ j.quaint.2007.09.034

Billia, E.M.E. 2011. Occurrences of Stephanorhinus kirchbergensis (Jäger, 1839) (Mammalia, Rhinocerotidae) in Eurasia. An account. Acta Palaeontologica Romaniae, 7:17-40.

Bogićević, K. and Nenadić, D. 2008. Early Pleistocene rodents (Rodentia, Mammalia) from Trlica near Plijevljja (Montenegro). Neues Jahrbuch für Geologie und Paläontologie Abhandlungen, 247(3):325-333. https://doi.org/10.1127/0077-7749/2008/0247-0325

Bona, F. and Sala, B. 2016. Villafranchian-Galerian mammal faunas transition in South-Western Europe. The case of the late Early Pleistocene mammal fauna of the Frantoio locality, Arda River (Castell'Arquato, Piacenza, Northern Italy). Geobios, 49:329-347. https://doi.org/ 10.1016/j.geobios.2016.06.002

Breda, M., Collinge, S.E., Parfitt, S.A., and Lister, A.M. 2010. Metric analysis of ungulate mammals in the early Middle Pleistocene of Britain, in relation to taxonomy and biostratigraphy: I: Rhinocerotidae and Bovidae. Quaternary International, 228(1-2):136-156. https://doi.org/10.1016/j.quaint.2010.05.010

Caccia, V. 1928. Su un cranio fossile di Rhinoceros Merchianus Etruriae (Falconer) rinvenuto in territorio di S. Colombano al Lambro con particolare considerazione dell'apparato dentale. Nuova Rassegna di Odontoiatria, 3:1-16.

Cantaluppi, G. 1969. II rinoceronte di S. Colombano al Lambro. Atti dell'Istituto Geologico dell'Università di Pavia, 20:67-81.

Cappellini, E., Welker, F., Pandolfi, L., Ramos-Madrigal, J., Samodova, D., Rüther, P.L., Fotakis, A.K., Lyon, D., Moreno-Mayar, V.J., Bukhsianidze, M., Jersie-Christensen, R.R., Mackie, M., Ginolhac, A., Ferring, R., Tappen, M., Palkopoulou, E., Dickinson, M.R., Stafford Jr, T.W., Chan, Y.L., Götherström, A., Nathan, S.K.S.S., Heintzman, P.D., Kapp, J.D., Kirillova, I., Moodley, Y., Agusti, J., Kahlke, R.-D., Kiladze, G., Martínez-Navarro, B., Liu, S., Velasco, M.S., Sinding, M.-H.S., Kelstrup, C.D., Allentoft, M.E., Orlando, L., Penkman, K., Shapiro, B., Rook, L., Dalén, L., Gilbert, M.T.P., Olsen, J.V., Lordkipanidze, D., Willerslev, E., 2019. Early Pleistocene enamel proteome sequences from Dmanisi resolve Stephanorhinus phylogeny. Nature. 574:103-107. https://doi.org/10.1038/s41586-019-1555-y

Cerdeño, E., 1993. Remarks on the Spanish Plio-Pleistocene Stephanorhinus etruscus (Rhinocerotidae). Comptes Rendus de l'Académie des sciences Paris, 317:1363-1367.

Ćirić, A. 1960. Die Chios-Fauna von Prebreza (Serbien). Bulletin de l'Institut de Recherches Géologique et Géophysique de Belgrade, 18(A):12-82. (In Serbian with German summary)

Codrea, V. and Czier, Z. 1991. Dicerorhinus etruscus brachycephalus (Perissodactyla, Mammalia) from the Pleistocene of Subpiatra (Tetchea village, Bihor County, Romania). Studia Universitatis "Babes-Bolyai". Geologia 36(2):27-33.

Codrea, V. and Dimitrijević, V.M. 1997. Stephanorhinus cf. hundsheimensis (Toula) (Rhinocerotidae, Mammalia) iz Trlice kod Pljevlja (Crna Gora). Annales Géologiques de la Péninsule Balkanique, 61(2):161-175. (In Serbian with English translation)

Cvetičanin, R. and Novković, M. 1975. The Bogovina Basin, p. 80-85. In Aksin, V. and Maksimović, B. (eds.), Geologija Srbije, Fosilna goriva, VII, Beograd. (In Serbian)

Dimitrijević, M.D. 1997. Geology of Yugoslavia. Geological Institute GEMINI Special Publication, Belgrade.

Dimitrijević, V.M. 1990. Preliminary results on the research on the mammalian fauna from Trlica near Pljevlje (Montenegro, Yugoslavia). Zbornik radova 12. Kongresa Geologa Jugoslavije (Stratigrafija, Sedimentologija, Paleontologija), 1:328-336. (In Serbian with English translation)

Dimitrijević, V.M. 1996. Upper Pleistocene mammals from cave deposits in Serbia. Acta Zoologica Cracoviensia, 39(1):117-120.

Dokmanovic, P., Jemcov, I., Milanovic, S., and Hajdin, B. 2003. Hydrogeological risk factors of dam and reservoir construction-case example Bogovina. Materials and Geoenvironment, 50(1):105-108.

Eisenmann, V., Alberdi, M.T., de Giuli, C., and Staesche, U. 1988. Methodology, p. 1-71. In Woodburne, M. and Sondaar, P. (eds.), Studying Fossil Horses, Vol. 1. E.J. Brill, Leiden. 
Forstén, A. 1986. A review of the Süssenborn horses and the origin of Equus hydruntinus Regalia. Quartärpaläontologie, 6:43-52.

Forstén, A. 1992. Mitochondrial-DNA time-table and the evolution of Equus: Comparison of molecular and paleontological evidence. Annales Zoologici Fennici, 28(3-4):301-309.

Forstén, A. and Dimitrijević, V. 2004. Pleistocene horses (genus Equus) in the central Balkans. Annales Géologiques de la Péninsule Balkanique, 65:55-75.

Fortelius, M., Mazza, P., and Sala, B. 1993. Stephanorhinus (Mammalia: Rhinocerotidae) of western European Pleistocene, with a revision of S. etruscus (Falconer, 1868). Palaeontographia Italica, 80:63-155.

Fukuchi, A., Nakaya, H., Takai, M., and Ogino, S. 2009. A preliminary report on the rhinoceros from Pliocene Udunga, Transbaikalia, Russia. Asian Paleoprimatology, 5:61-98.

Gentry, A.W. 1999. Fossil ruminants (Mammalia, Artiodactyla) from Westbury Cave, p. 139-174. In Andrews, P., Cook, J., Currant, A., and Stringer, C. (eds.), Westbury Cave: The Natural History Museum Excavations 1976-1984. Western Academic and Specialist Press Ltd., Bristol.

Guérin, C. 1980. Les Rhinocéros (Mammalia, Perissodactyla) du Miocène terminal au Pléistocène supérieur en Europe occidentale - Comparaison avec les espèces actuelles. Thèse Doctorat d'Etat et Sciences, Université de Lyon I, Documents des Laboratoires de Géologie de Lyon 79, 1185 pp., Lyon. (English, German, and Russian summaries)

Guérin, C., Barychnikov, G., and Mejloumian, S.K. 1992. Survivance tardive d'une forme archaïque dans le Pléistocène du Caucase: le Dicerorhinus etruscus brachycephalus du gisement moustérien d'Erivan I (Arménie) (Mammalia Rhinocerotidae). Bulletin Mensuel de la Société Linnéenne de Lyon, 61(6):166-174.

Handa, N. and Pandolfi, L. 2016. Reassessment of the middle Pleistocene Japanese rhinoceroses (Mammalia, Rhinocerotidae) and paleobiogeographic implications. Paleontological Research, 20(3):247-260. https://doi.org/10.2517/2015PR034

Kahlke, H.-D. 1965. Die Rhinocerotiden-Reste aus den Tonen von Voigtstedt in Thüringen. Paläontologische Abhandlungen, A Il:451-519.

Kahlke, H.-D. 1969. Die Rhinocerotiden-Reste aus den Kiesen von Süßenborn bei Weimar. Paläontologische Abhandlungen, A III:667-708.

Kahlke, R.D. and Kaiser, Th.M. 2011. Generalism as a subsistence strategy - Advantages and limitations of the highly flexible feeding traits of Pleistocene Stephanorhinus hundsheimensis (Rhinocerotidae, Mammalia). Quaternary Science Reviews, 30:2250-2261. https://doi.org/ 10.1016/j.quascirev.2009.12.012

Koenigswald, W.v., Holly Smith, V., and Keller, B.T. 2007. Supernumerary teeth in a subadult rhino mandible (Stephanorhinus hundsheimensis) from the Middle Pleistocene of Mosbach in Wiesbaden (Germany). Paläontologische Zeitschrift, 81:416-428.

Konidaris, G.E., Tourloukis, V., Kostopoulos, D.S., Thompson, N., Giusti, D., Michailidis, D., Koufos, G.D., and Harvati, K. 2015. Two new vertebrate localities from the Early Pleistocene of Mygdonia Basin (Macedonia, Greece): Preliminary results. Comptes Rendus Palevol, 14:353-362. https://doi.org/10.1016/j.crpv.2015.05.004

Lacombat, F. 2005. Les Rhinocéros fossiles des sites préhistoriques de l'Europe méditerranéenne et du Massif Central, Paléontologie et implications biochronologiques. British Archaeological Research International Series, 1419:1-175.

Lacombat, F. 2006a. Morphological and biometrical differentiation of the teeth from Pleistocene species of Stephanorhinus (Mammalia, Perissodactyla, Rhinocerotidae) in Mediterranean Europe and the Massif Central. Palaeontographica, Beiträge zur Naturgeschichte der Vorzeit, Abteilung A: Paläozoologie - Stratigraphie, 274:71-111.

Lacombat, F. 2006b. Pleistocene rhinoceroses in Mediterranean Europe and in the Massif Central (France). Courier Forschinstitut Senckenberg, 256:57-69.

Lacombat, F. 2007. Phylogeny of the genus Stephanorhinus in the Plio-Pleistocene of Europe. Hallesches Jahrbuch für Geowissenschaften, 23:63-64.

Lacombat, F. 2010. Estudio paleontológico de Stephanorhinus hundsheimensis de Fuenta Nueva-3 y Barranco León, p. 237-246. In Toro, I., Martínez-Navarro, B., and Agustí, J. (eds.), Ocupaciones Humanas en el Pleistoceno inferior y medio de la cuenca de Guadix-Baza, Memoria Científica. Junta de Andalucía. Consejería de Cultura. E.P.G. Arqueología Monográfico, Sevilla. 
Lacombat, F. and Moullé, P.-É. 2005. Description paléontologique du Stephanorhinus hundsheimensis (Toula, 1902) du Pléistocène Inférieur de la Tour de Grimaldi (Ligurie, Italie). Bulletin du Musée d'Anthropologie Préhistoriques de Monaco, 44:33-38.

Lisiecki, L.E. and Raymo, M.E. 2005. A Pliocene-Pleistocene stack of 57 globally distributed benthic $\delta^{180}$ records. Paleoceanography, 20:PA1003. https://doi.org/10.1029/ 2004PA001071

Madurell-Malapeira, J., Minwer-Barakat, R., Alba, D.M., Garcés, M., Gómez, M., Aurell-Garrido, J., Ros-Montoya, S., Moyà-Solà, S., and Berástegui, X. 2010. The Vallparadís section (Terrassa, Iberian Peninsula) and the latest Villafranchian faunas of Europe. Quaternary Science Reviews, 29:3972-3982. https://doi.org/10.1016/j.quascirev.2010.09.020

Maran, A. 2010. Valuing the geological heritage of Serbia. Bulletin of the Natural History Museum in Belgrade, 3:47-66.

Marković, Z. 1998. Woolly rhinoceros Coelodonta antiquitatis (Blumenbach, 1803) from Pleistocene of Serbia. Bulletin of the Natural History Museum in Belgrade A, 47-50:217-237.

Marra, F., Pandolfi, L., Petronio, C., Di Stefano, G., Gaeta, M., and Salari, L. 2014. Reassessing the sedimentary deposits and vertebrate assemblages from Ponte Galeria area (Rome, central Italy): an archive for the Middle Pleistocene faunas of Europe. Earth-Science Reviews, 139:104-122. https://doi.org/10.1016/j.earscirev.2014.08.014

Mazza, P. 1988. The Tuscan Early Pleistocene rhinoceros Dicerorhinus etruscus. Palaeontographia Italica, 75:1-87.

Mazza, P., Sala, B., and Fortelius, M. 1993. A small latest Villafranchian (late Early Pleistocene) rhinoceros from Pietrafitta (Perugia, Umbria, central Italy), with notes on the Pirro and Westerhoven rhinoceroses. Palaeontographia Italica, 80:25-50.

McKenna, M.C. and Bell, S.K. 1997. Classification of Mammals above the Species Level. Columbia University Press, New York.

Milanović, S. 2015. Speleology and cave diving as a base for tapping structure design, p. 470489. In Stevanović, Z. (ed.), Karst Aquifers - Characterization and Engineering. Springer, Cham. https://doi.org/10.1007/978-3-319-12850-4

Mkrtchyan, R., Belmaker, M., Hynek, S., Belyaeva, E., and Aslanian, S. 2011. Stephanorhinus cf. hundsheimensis from Kurtan, a new early Pleistocene site in the Lori Plateau, Armenia Implications for the biogeography of Rhinocerotidae. Abstracts of the $71^{\text {st }}$ Annual Meeting of the Society of Vertebrate Paleontology, Paris Las Vegas, Nevada, November 2-5, 2011:159160.

Monesi, E., Muttoni, G., Scardia, G., Felletti, F., Bona, F., Sala, B., Tremolada, F., Francou, C., and Raineri, G. 2016. Insights on the opening of the Galerian mammal migration pathway from magnetostratigraphy of the Pleistocene marine-continental transition in the Arda River section (northern Italy). Quaternary Research, 86:220-231. https://doi.org/10.1016/ j.yqres.2016.07.006

Musil, R. 1969. Die Equiden-Reste aus dem Pleistozan von Süssenborn bei Weimar. Paläontologische Abhandlungen, Abteilung A, Paläozoologie, III(3/4):617-666.

Nedeljković, D. 2006. Coelodonta antiquitatis (Blumenbach, 1799) iz nanosa reke Save kod Ravnja. Rad Muzeja Vojvodine, 47-48:67-76. (In Serbian with English abstract)

Pandolfi, L., Boscato, P., Crezzini, J., Gatta, M., Moroni, A., Rolfo, M.F., and Tagliacozzo, A. 2017b. Late Pleistocene last occurrences of narrow-nosed rhinoceros Stephanorhinus hemitoechus (Mammalia, Perissodactyla) in Italy. Rivista Italiana di Paleontologia e Stratigrafia, 123(2):177-192. https://doi.org/10.13130/2039-4942/8300

Pandolfi, L., Cerdeño, E., Codrea, V., and Kotsakis, T. 2017a. Biogeography and chronology of the Eurasian extinct rhinoceros Stephanorhinus etruscus (Mammalia, Rhinocerotidae). Comptes Rendus Palevol, 16(7):762-773. https://doi.org/10.1016/j.crpv.2017.06.004

Pandolfi, L. and Erten, H. 2017. Stephanorhinus hundsheimensis (Mammalia, Rhinocerotidae) from the late early Pleistocene deposits of the Denizli Basin (Anatolia, Turkey). Geobios, 50(1):65-73. https://doi.org/10.1016/j.geobios.2016.10.002

Pandolfi, L., Gaeta, M., and Petronio, C. 2013. The skull of Stephanorhinus hemitoechus (Mammalia, Rhinocerotidae) from the Middle Pleistocene of Campagna Romana (Rome, Central Italy): biochronological and paleobiogeographic implications. Bulletin of Geosciences, 88(1):51-62. https://doi.org/10.3140/bull.geosci.1363

Pandolfi, L., Gasparik, M., and Magyar, I. 2016. Rhinocerotidae from the Upper Miocene deposits of the Western Pannonian Basin (Hungary): implications for migration routes and biogeography. Geologica Carpathica, 67(1):69-82. https://doi.org/10.1515/geoca-2016-0004 
Pandolfi, L., Gasparik, M., and Piras, P. 2015. Earliest occurrence of "Dihoplus" megarhinus (Mammalia, Rhinocerotidae) in Europe (Late Miocene, Pannonian Basin, Hungary): Palaeobiogeographical and biochronological implications. Annales de Paléontologie, 101:325-339. https://doi.org/10.1016/j.annpal.2015.09.001

Pandolfi, L., Grossi, F., and Frezza, V. 2015. New insights into the Pleistocene deposits of Monte delle Piche, Rome, and remarks on the biochronology of continental Hippopotamus (Mammalia, Hippopotamidae) and Stephanorhinus etruscus (Mammalia, Rhinocerotidae) in Italy. Estudios Geologicos, 71:16(e026). https://doi.org/10.3989/egeol.41796.337

Pandolfi, L. and Marra, F., 2015. Rhinocerotidae (Mammalia, Perissodactyla) from the chronostratigraphically constrained Pleistocene deposits of the urban area of Rome (Central Italy). Geobios, 48(2):147-167. https://doi.org/10.1016/j.geobios.2015.02.003

Pandolfi, L. and Petronio, C. 2011. Stephanorhinus etruscus (Falconer, 1868) from Pirro Nord (Apricena, Foggia, Southern Italy) with notes on the late Early Pleistocene rhinoceroses of Italy. Rivista Italiana di Paleontologia e Stratigrafia, 117:173-187. https://doi.org/10.13130/ 2039-4942/5969

Pavlova, M.V. 1925. Iskopaemye mlekupitayushchie iz Tiraspol'skogo gravya Khersonskoy gubernii. Memuary Geologicheskogo Otdelya Obshchestva Lyubiteley Estestvoznanya, Antropologii i Etnografii, 3:50-55. (In Russian)

Pavlović, M. 1963. Dicerorhinus aff. sansaniensis (Lart.) iz mladjeg Miocena Srbije. Annales Géologiques de la Péninsule Balkanique, 30:63-75. (In Serbian with German summary)

Persico, D., Billia, E.M.E., Ravara, S., and Sala, B. 2015. The skull of Stephanorhinus kirchbergensis (Jäger, 1839) (Mammalia, Rhinocerotidae) from Spinadesco (Cremona, Lombardia, Northern Italy): morphological analyses and taxonomical remarks - An opportunity for revising the three other skulls from the Po Valley. Quaternary Science Reviews, 109:28-37. https://doi.org/10.1016/j.quascirev.2014.11.022

Petrović, D. 1977. Morfologija i geneza Bogovinske pećine. Zbornik radova Geografskog instituta „Jovan Cvijić" Beograd, 29:81-103.

Pušić, M. and Stevanović, Z. 1994. Hydrodynamic model of Bogovina karst aquifer. Annales Géologiques de la Péninsule Balkanique, 58(2):303-321.

Ravazzi, C., Pini, R., and Breda, M. 2009. Reconstructing the palaeoenvironments of the Early Pleistocene mammal faunas from the pollen preserved on fossil bones. Quaternary Science Reviews, 28:2940-2954. https://doi.org/10.1016/j.quascirev.2009.07.022

Ros-Montoya, S., Martínez-Navarro, B., Espigares, M.-P., Guerra-Merchán, A., García-Aguilar, J.M., Piñero, P., Rodríguez-Rueda, A., Agustí, J., Oms, O., and Palmqvist, P. 2017. A new Ruscinian site in Europe: Baza-1 (Baza basin, Andalusia, Spain). Comptes Rendus Palevol, 16: 746-761. https://doi.org/10.1016/j.crpv.2017.05.005

Santafé-Llopis, J. and Casanovas-Cladellas, Vte, M.L. 1987. Dicerorhinus etruscus brachycephalus (Mammalia, Perissodactyla) de los yacimientos pleistocénicos de la cuenca de Guadix-Baza (Venta Micena y Huéscar) (Granada, Espana). Paleontologia i Evolutió, Memoria Especial, 1:237-254.

Schreiber, H.D. 2005. Osteological investigations on skeleton material of rhinoceroses (Rhinocerotidae, Mammalia) from the early Middle Pleistocene locality of Mauer near Heidelberg (SW-Germany). Quaternaire. Hors-série, 2:103-111.

Sher, A.V. 1997. An Early Quaternary bison population from Untermassfeld: Bison menneri sp. nov., p. 101-180. In Kahlke, R.-D. (ed.), Das Pleistozän von Untermassfeld bei Meiningen (Thüringen). Monographien des Römisch-Germanischen Zentralmuseums Mainz 40.

Skinner, M.F., Hibbard, C.W., Gutentag, E.D., Smith, G.R., Lundberg, J.G., Holman, J.A., Feduccia, J.A., Rich, P.V., 1972. Early Pleistocene pre-glacial and glacial rocks and faunas of north-central Nebraska. Bulletin of the American Museum of Natural History, 148:77-148.

Smith, J.B. and Dodson, P. 2003. A proposal for a standard terminology of anatomical notation and orientation in fossil vertebrate dentitions. Journal of Vertebrate Paleontology, 23(1):1-12. https://doi.org/10.1671/0272-4634(2003)23[1:APFAST]2.0.CO;2

Stefanović, I. 2002-03. The fauna of Prebreza (southern Serbia) and its position within the Mammalian Neogene units. Annales Géologiques de la Péninsule Balkanique, 65:77-84. https://doi.org/10.2298/GABP0301077S

Stefanović, I. and Mijović, D. 2004. The Middle Miocene fossil site Prebreza in Southern Serbia. Proceedings of the Conference "Geological Heritage Concept, Conservation and Protection Policy in Central Europe”, Polish Geological Institute Special Papers, 13:209-212. 
Stuart, A.J. and Lister, A.M. 2007.Patterns of Late Quaternary megafaunal extinctions in Europe and northern Asia. Courier Forschungsinstitut Senckenberg, 259:287-297.

Stuart, A.J. and Lister, A.M. 2012. Extinction chronology of the woolly rhinoceros Coelodonta antiquitatis in the context of late Quaternary megafaunal extinctions in northern Eurasia. Quaternary Science Reviews, 51:1-17. https://doi.org/10.1016/j.quascirev.2012.06.007

Szabó, P., Kocsis, L., Vennemann, T., Pandolfi, L., Kovács, J., Martinetto, E., and Demény, A. 2017. Pliocene-Early Pleistocene climatic trends in the Italian Peninsula based on stable oxygen and carbon isotope compositions of rhinoceros and gomphothere tooth enamel. Quaternary Science Reviews, 157:52-65. https://doi.org/10.1016/j.quascirev.2016.11.003

Toula, F. 1902. Das Nashorn von Hundsheim Rhinoceros (Ceratorhinus Osborn) hundsheimensis nov. form. Mit Ausführungen über die Verhältnisse von elf Schädeln von Rhinoceros (Ceratorhinus) sumatrensis. Abhandlungen der Kaiserlich-Königlichen Geologischen Reichsanstalt, XIX(1):1-92.

Van Asperen, E.N., Stefaniak, K., Proskurnyak, I., and Ridush, B. 2012. Equids from Emine-BairKhosar Cave (Crimea, Ukraine): co-occurrence of the stenonid Equus hydruntinus and the caballoid E. ferus latipes based on skull and postcranial remains. Palaeontologia Electronica, 15:5A. https://doi.org/10.26879/280

palaeo-electronica.org/content/2012-issue-1-articles/124-equids-from-emine-bair-khosar

Van der Made, J. 2000. A preliminary note on the rhinos from Bilzingsleben. Praehistoria Thuringica, 4:41-64.

Van der Made, J. 2010. The rhinos from the middle Pleistocene of Neumark-Nord (SaxonyAnhalt). Veröffentlichungen des Landesamtes für Archäologie, 62:432-527.

Van der Made, J. and Montoya, P. 2007. Rinocerontes del Pleistoceno de El Baradello, Plaça de la República y El Molinar en Alcoy, España. Recerques del Museu d'Alcoi, 16:7-18.

Veselinović, M., Antonijević, I., Krstić, B., Mićić, I., Milošaković, R., Rakić, B., and Banković, V., 1964. Osnovna geološka karta SFRJ 1:100000 - list Boljevac. Savezni geološki zavod, Beograd. (In Serbian)

Vislobokova, I.A. and Agadjanian, A.K. 2015. New data on large mammals of the Pleistocene Trlica fauna, Montenegro, the Central Balkans. Paleontological Journal, 49(6):651- 667. https://doi.org/10.1134/S0031030115060143

Vislobokova, I.A. and Agadjanyan, A.K. 2016. New data on age of the Pleistocene fauna from the Trlica locality (Montenegro, Central Balkans) and its correlation with other faunas of Europe. Stratigraphy and Geological Correlation, 24(2):188-202. https://doi.org/10.1134/ S0869593816020088

Zervanová, J. 2014. Vyhynutí Zástupcovia Celade Rhinocerotidae z Územia Slovenska Celkové Zhodnotenie. Unpublished PhD Thesis, Comenius University of Bratislava, Bratislava. (In Slovak with English abstract) 